\title{
The Materials Flow of Mercury in the Economies of the United States and the World
}

by John L. Sznopek' and Thomas G. Goonan'

Open-File Report 00-281

2000

This report is preliminary and has not been reviewed for conformity with U.S. Geological Survey editorial standards or with the North American Stratigraphic Code. Any use of trade, firm, or product names is for descriptive purposes only and does not imply endorsement by the U.S.

Government

U.S. DEPARTMENT OF THE INTERIOR

U.S. GEOLOGICAL SURVEY

${ }^{1}$ Denver, Colorado 


\section{CONTENTS}

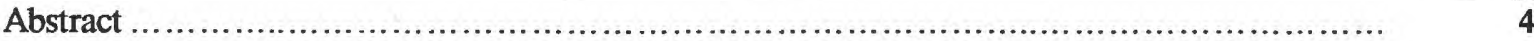

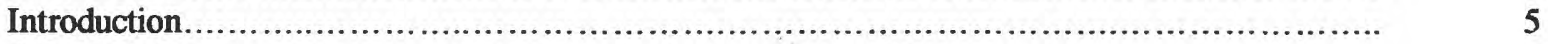

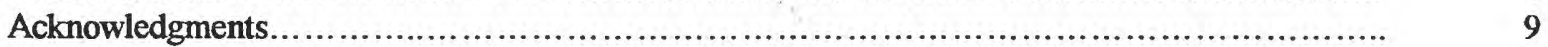

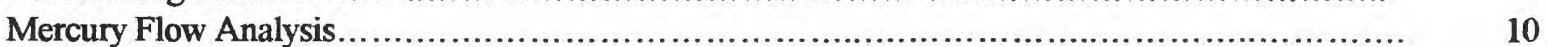

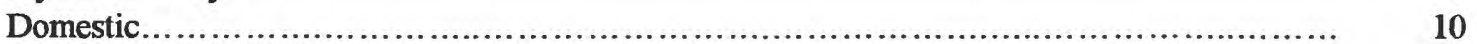

Emissions to the Environment................................................ 15

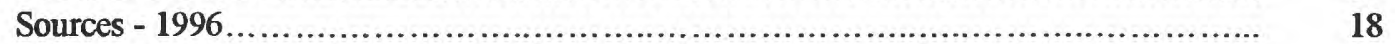

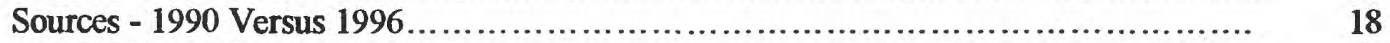

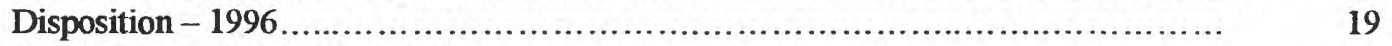

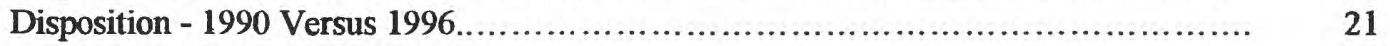

Case study - Chlor-alkali .................................................... 22

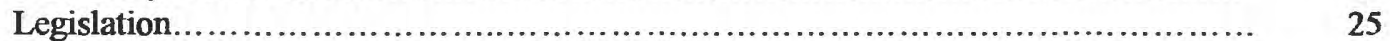

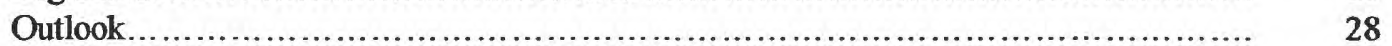

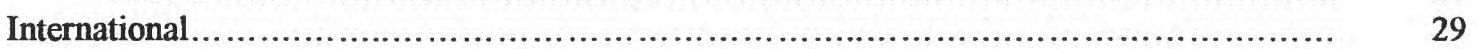

Emissions to the Environment ....................................................... 29

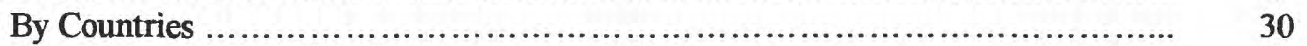

Brazil.............................................................. 30

Germany.......................................................... 30

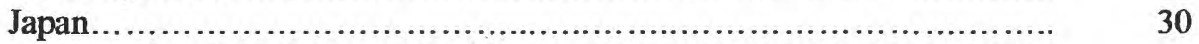

New Guinea ....................................................... 31

Russia.............................................................. 31

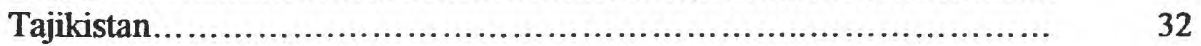

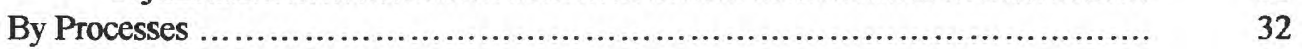

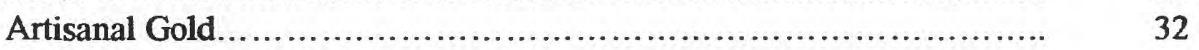

Coal Combustion..................................................... 33

Oil and Natural Gas Combustion...................................... 35

Sources......................................................................... 35

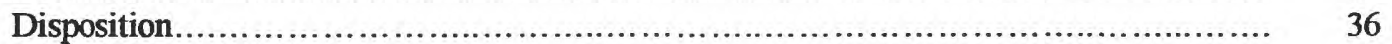

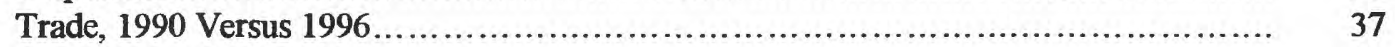

Case Study - Chlor-alkali....................................................... 38

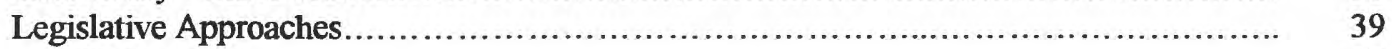

Netherlands................................................................. 39

Sweden and Denmark ......................................................... 40

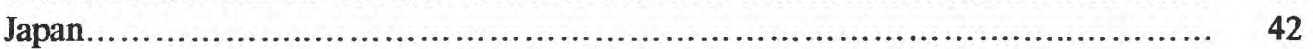

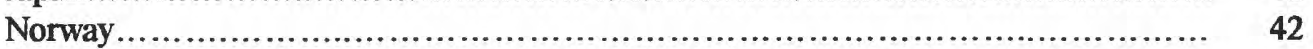

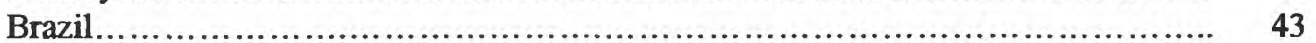

Russia, Ukraine, Kyrgyzstan ................................................... 43

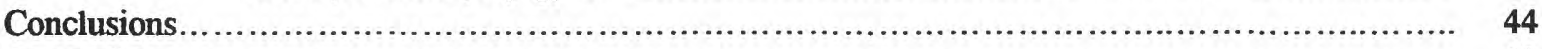

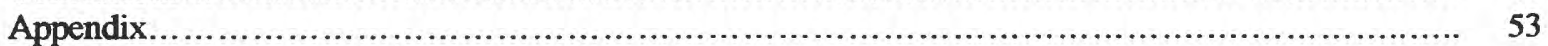

\section{FIGURES}

1. Generic materials flow diagram ........................................................... 5

2. Histogram showing components of U.S. apparent supply of mercury $(1970-1998) \ldots \ldots \ldots \ldots \ldots . .11$

3. Graph showing U.S. industrial reported consumption of mercury $(1970-1997) \ldots \ldots \ldots \ldots \ldots \ldots . .13$

4. Graph showing U.S. apparent supply and reported consumption of mercury $(1970-1998) \ldots \ldots \ldots . \quad 14$

5-13. Diagrams showing:

5. Domestic flow of mercury in 1996

6. Domestic flow of mercury in 1990: natural and incidental releases, and mined, recycled, and

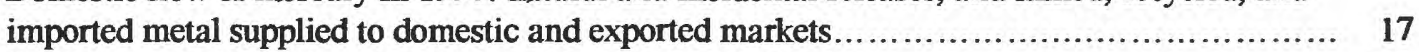

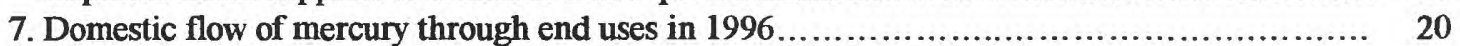

8. Domestic flow of mercury in 1990: products manufactured, in use, and obsolete............... 22 
9. 1996 mercury flow in the U.S. mercury cell sector, chlor-alkali industry .................... 23

10. 1990 mercury flow in the U.S. mercury cell sector, chlor-alkali industry ...................... 25

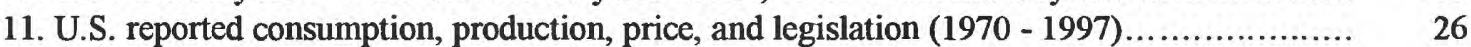

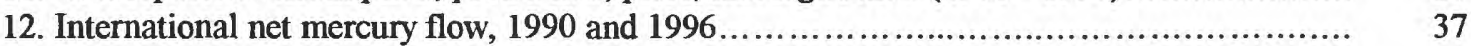

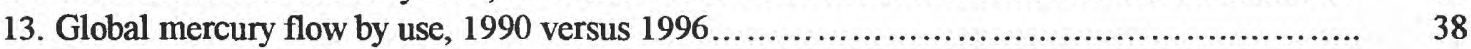

TABLES

Page

1. Legislation and programs affecting mercury ................................................ 27

2. World chlorine capacity from chlor-alkali plants.............................................. 39

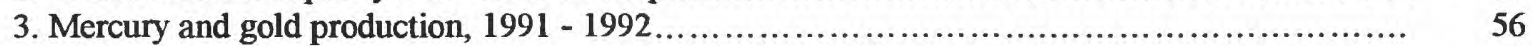

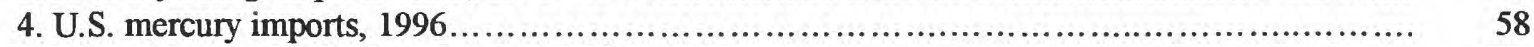

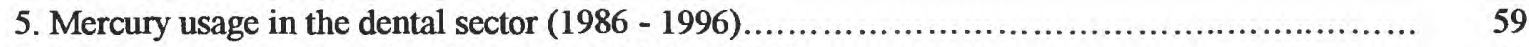

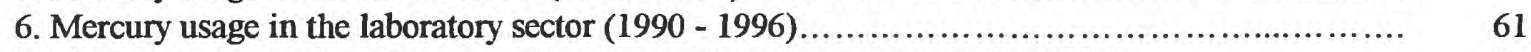

7. Mercury usage in the measurement and control devices sector $(1990-1996) \ldots \ldots \ldots \ldots \ldots \ldots \ldots \ldots \ldots \ldots \ldots \ldots$

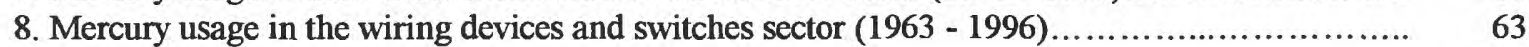

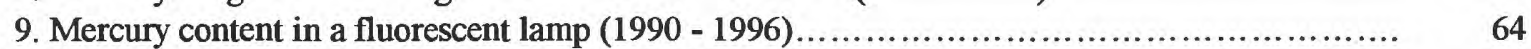

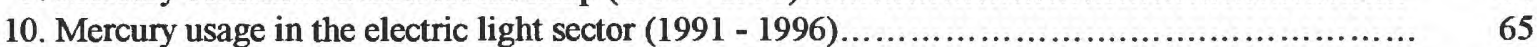

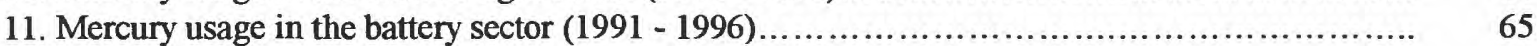

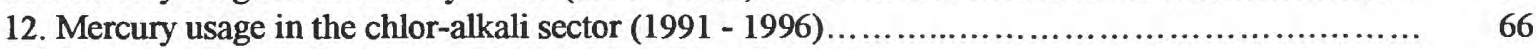

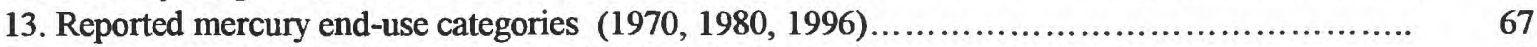

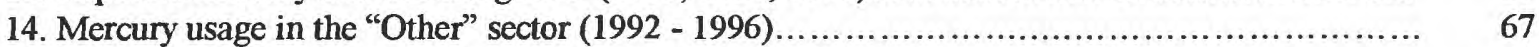

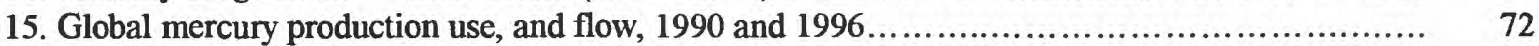




\begin{abstract}
Although natural sources of mercury exist in the environment, measured data and modeling results indicate that the amount of mercury released into the biosphere has increased since the beginning of the industrial age. Mercury is naturally distributed in the air, water, and soil in minute amounts, and can be mobile within and between these media. Because of these properties and the subsequent impacts on human health, mercury was selected for an initial materials flow study, focusing on the United States in 1990.

This study was initiated to provide a current domestic and international analysis. As part of an increased emphasis on materials flow, this report researched changes and identified the associated trends in mercury flows; it also updates statistics through 1996. In addition to domestic flows, the report includes an international section, because all primary mercuryproducing mines are currently foreign, 86 percent of the mercury cell sector of the worldwide chlor-alkali industry is outside the United States, there is a large international mercury trade $\left(1,395 t^{1}\right.$ in 1996), and environmental regulations are not uniform or similarly enforced from country to country.
\end{abstract}

Environmental concerns have brought about numerous regulations that have dramatically decreased both the use and the production of mercury since the late 1980's. Our study indicates that this trend is likely to continue into the future, as the world eliminates the large mercury inventories that have been stockpiled to support prior industrial processes and products.

\footnotetext{
${ }^{1} \mathrm{t}=$ metric tons throughout the report.
} 


\section{INTRODUCTION}

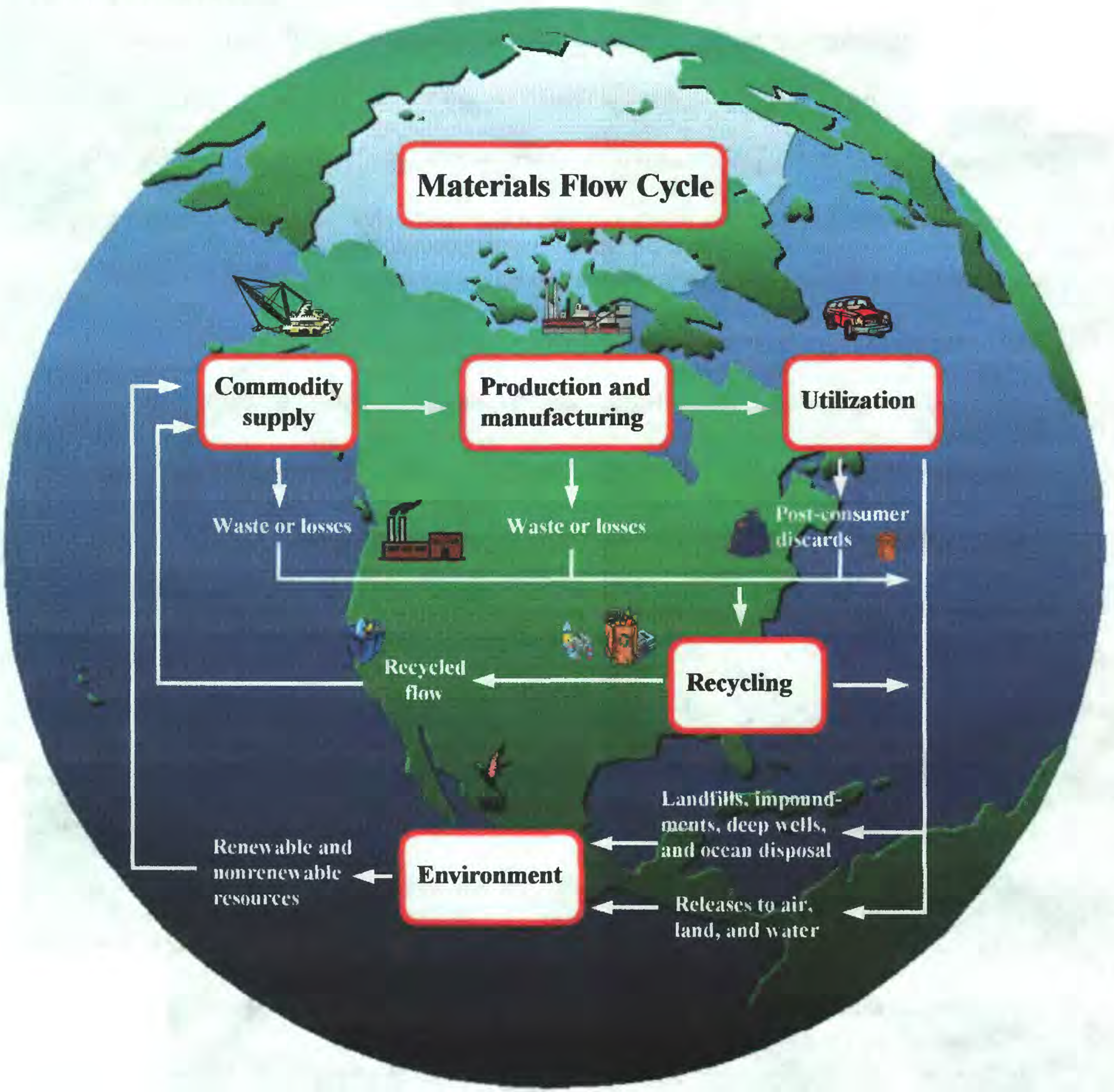

Materials flow studies provide insights into the dynamics that affect flow, that quantity of

a specific material moving from one medium and (or) location to another, in this case, mercury.

These studies permit decision-makers to leverage knowledge of materials flow into more efficient management with respect to social goals. For example, policy might be directed toward 
minimizing environmental impact by adjusting some aspect of a particular material's flow. Materials flow studies address the life cycle of materials from extraction, through processing, manufacturing, use, re-use, and disposition. Materials flow studies characterize not only the movement of materials (including losses to the environment), but also the stocks: a stock (inventories or products in use) is where a specified material resides, relatively unaltered, for a period of time. For more information on materials flow studies, see URL http://minerals.usgs.gov/minerals/mflow/.

Mercury was selected for study because of its demonstrated toxic effects on the environment and its potential for impact on human health. Mercury is widely dispersed throughout air, soils, and water. It is mobile within the environment, so any policy-oriented solution or technological advancement that limits the amount going into the environment could yield benefits.

A materials flow study of mercury in the United States was last published by the U.S. Bureau of Mines in 1994 and contained data through 1990 (Jasinski, 1994). This study updates the information through 1996. This year was selected because the most complete set of data was available, and estimations and assumptions were thus held to a minimum. In that brief span of time between 1990 and 1996, major changes, precipitated mainly through government policy, have occurred within the mercury lifecycle. One purpose of this report is to document those changes; another is to identify trends in mercury production and usage for the future. More recent data from 1998 confirm that these trends have continued.

Mercury and its compounds have a long history of human use. It has been found in Egyptian tombs dated back to $1500 \mathrm{BC}$. Cinnabar, a mercury-sulfide mineral, was used as a red pigment in early Egypt and China. Spiritualists associated mercury metal with mystic qualities, 
and alchemists tried to transform it into gold. It was used for centuries as a curative for syphilis. Modern uses for mercury include electrical switches, thermometers, dental amalgams, lighting (mercury vapor and fluorescent lamps), flow meters, batteries, fungicides, electrochemistry, catalysis, explosives, gold recovery, and bactericides.

Mercury is the only metal that is liquid at room temperature $\left(20^{\circ} \mathrm{C}\right)$. Mercury is a good electrical conductor and is highly resistant to corrosion. It has a high charge density to weight ratio, which makes mercury batteries preferable for space missions. Mercury is easily separated from its parent minerals through the application of heat, enhancing its ability to be recovered in a pure state. Mercury has the highest solubility in water of any metal, and easily vaporizes into the air; these two properties make it very mobile in the environment.

Mercury vapor can be carried over great distances in the atmosphere, and be deposited into lakes and streams. Under anaerobic (oxygen-deficient) conditions, deposited mercury undergoes biochemical change to become methylmercury. Methylmercury can enter and proceed through the food chain, bio-accumulating in fish tissue to levels that can endanger populations of animals and humans that feed farther up the chain. Government advisories, which warn consumers about mercury-contaminated fish, have become more frequent throughout both the industrialized and the developing world. These concerns have been the main impetus for greater regulatory control of mercury.

Although natural sources of mercury exist in the environment, such as mineral deposits, hot springs, and volcanoes, increased amounts of mercury have entered into the biosphere from anthropogenic (human-derived) sources. Some of the more significant anthropogenic mercuryemission sources include municipal and medical waste incineration, coal combustion, manufacturing process leaks, and the leaching of solid wastes in landfills. 
In the past, management and regulatory responses to the growing mercury problem have generally been constrained by a lack of information on sources, method of transport, chemical interaction with the environment, and biological significance of mercury in the environment. However, significant research advances during the past decade have allowed scientists to identify, measure, and examine the important biogeochemical processes that determine the fate and biological availability of mercury in the environment. A detailed discussion of these issues is outside the scope of this study, but the following references may be helpful: U.S. EPA, "Mercury Study Report to Congress," 1997; "Mercury as a global pollutant," in Water, Air, and Soil Pollution, v. 80, 1995; "Mercury pollution - Integration and synthesis," edited by Carl J. Watras and John W. Huckabee, 1994; and "Mercury as an environmental pollutant," in Water, Air, and Soil Pollution, v. 56, 1991.

A primary requirement for any materials flow analysis is substantiated data. Where U.S. data were unavailable either because they were not collected or not reported, certain calculations were made based on estimations and assumptions. Flow splits (numerical fractions into which a single flow from one stock distributes to two or more different stocks) were estimated if data were unavailable. In addition, approximations were made for by-product mercury production from gold mines, mercury incorporated in lighting fixtures, and disposal splits between recycling and land filling. As mercury in the environment is an international issue, global interregional mercury flows were estimated for 1990 and 1996. Unless specifically noted, the figures in this study were produced using U.S. Geological Survey's data (Mineral Commodity Summaries, 1997 - 1998, and Minerals Yearbook, 1995 - 1997). The details concerning the quantification of various textual and graphical parameters mentioned are contained in the Appendix. 


\section{Acknowledgments}

We are very appreciative to Stephen M. Jasinski, U.S. Geological Survey mineral commodity

specialist, for sharing his prior research, methodologies, and associated references, and to Robert

G. Reese, U.S. Geological Survey mineral commodity specialist, for his assistance. 


\section{MERCURY FLOW ANALYSIS}

\section{Domestic}

U.S. mercury apparent supply ${ }^{2}$ is shown in figure 2 for the period 1970 to 1998 .

These data suggest three different time periods, characterized by different market dynamics.

From 1970 to 1986 , U.S. primary mercury mine production and net imports contributed significant amounts to the mercury market. Net imports, during this first period, grew strongly from 33 percent of apparent supply in 1970 to 83 percent in 1974, and then decreased slowly to 58 percent in 1978 . Thereafter, net imports plunged to 13 percent of apparent supply in 1980 , remaining steady until 1984, when they advanced to 42 percent. The market share of U.S. primary mercury mine production was inversely correlated to net imports, indicating direct substitution of one for the other. Throughout this period, U.S. secondary mercury production from scrap supplied between 4 and 26 percent of apparent supply.

The second distinct period spanned 1986 - 1992; it was characterized by a rapid decrease in U.S. apparent mercury supply, caused by legislation to eliminate mercury in batteries (54 percent of demand for mercury in 1984, and 2 percent in 1992) (fig. 3). Also contributing to the reduction in apparent mercury supply was the elimination of mercury in paint as a fungicide (16 percent in 1989, and 0 percent in 1992). U.S. stockpile releases continued through this period, and secondary production showed little change. From 1989 through 1992, the United States exported mercury, most likely from industry stocks held to manufacture batteries and paint additives, but also from large U.S. Government stockpile releases (1991 and 1992). Mine production of primary mercury in the United States ceased in 1991.

\footnotetext{
${ }^{2}$ Apparent supply includes production (primary and secondary) + net imports + government stockpile releases.
} 


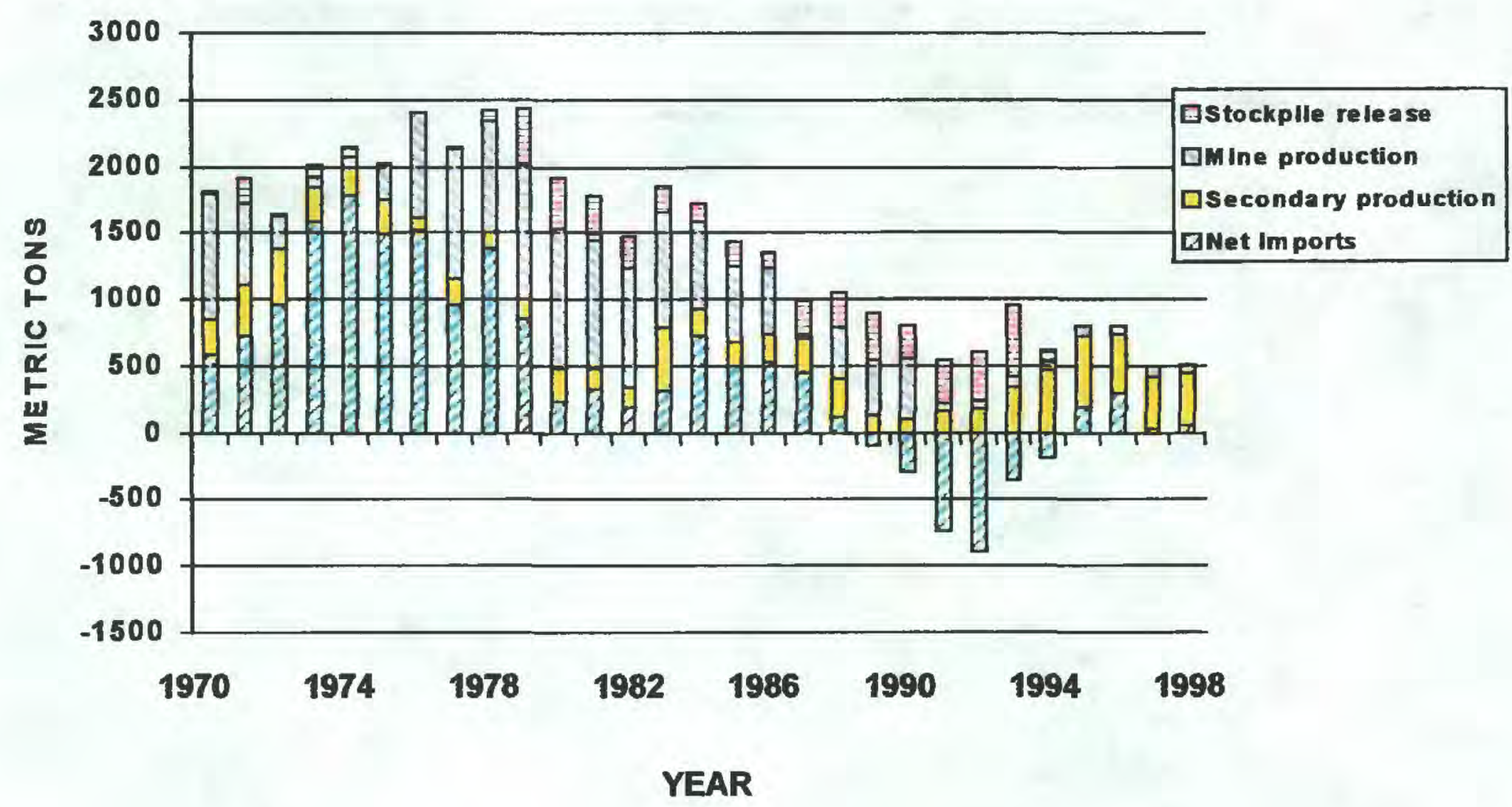

Figure 2. Components of U.S. apparent supply of mercury (1970 - 1998).

The third distinct historical period, from 1993 to 1998, was one of adjustment to current conditions where apparent mercury supply had bottomed out. This period is characterized by increases to consumer and producer stocks, increasing net imports, no primary mine production, and greatly expanded secondary mercury production, supported by favorable (State-level) legislation mandating mercury recycling.

The term "reported consumption" has a long history and was used in the past by the U.S. Bureau of Mines (USBM) and is currently used by the U.S. Geological Survey (USGS). Reported consumption is collected data from surveyed respondents and represents the mercury metal purchased from producers (at market prices, at time of purchase) by nonproducers. Distribution of U.S. mercury reported consumption among industrial sectors for the period 1970 through 1997 is shown in figure 3. This illustration demonstrates the details of the distribution of 
mercury among market sectors, and shows the major impact of curtailment of the use of mercury for batteries and paints, illustrating the discussion of figure 2 . 


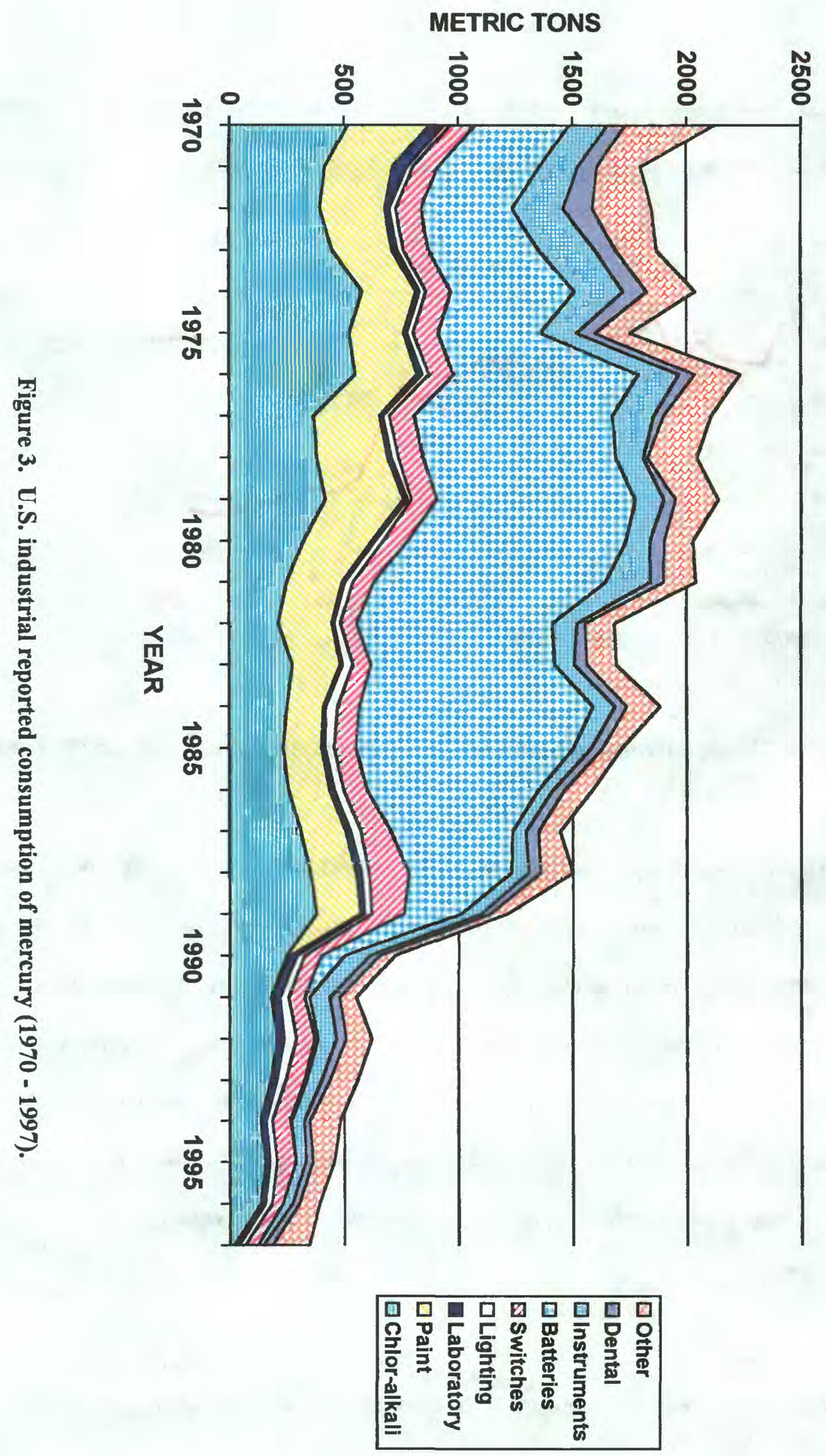


Figure 4 compares apparent mercury supply with reported consumption. If stock changes were added to apparent supply, the result would track more closely with reported consumption.

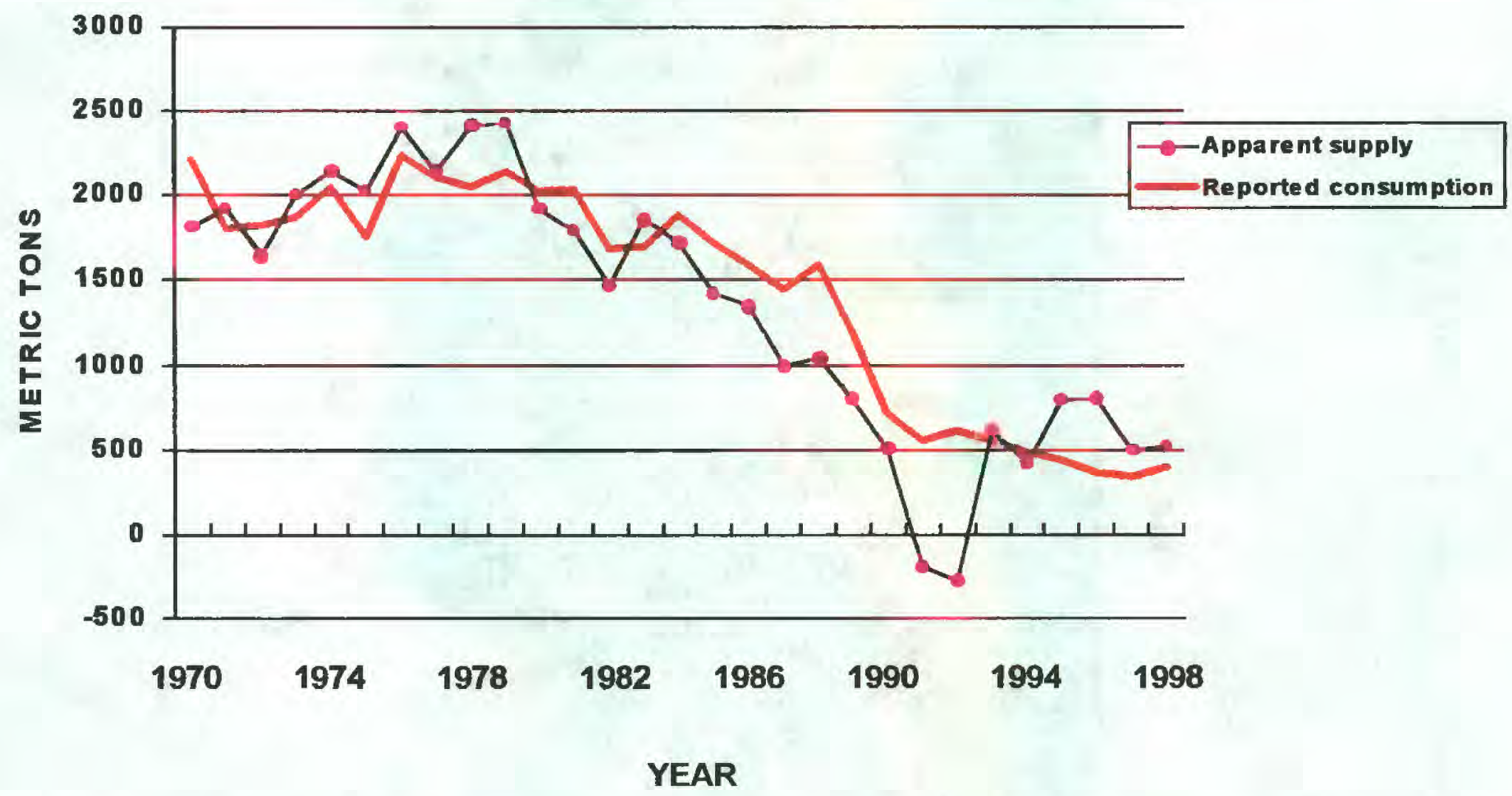

Figure 4. U.S. apparent supply and reported consumption of mercury (1970 - 1998).

In figure 4, when apparent supply exceeds the reported consumption line, inventories of producers and consumers are increased that year, and where the apparent supply fails to reach the reported consumption line, inventories are depleted. Between 1984 and 1989, mercury apparent supply never achieved the full reported consumption level; indicating continual consumer and producer inventory declines ${ }^{3}$. During 1991 and 1992, when net imports were negative (exports are greater than imports) and reported consumption was leveling off from the steep decline experienced between 1983 and 1991, the United States was actually depleting its total mercury stocks.

\footnotetext{
${ }^{3}$ See discussion in Appendix, p. 54, regarding how this observation may not be consistent for the years 1978 1988.
} 


\section{Emissions to the Environment}

In 1996, the burning of fossil fuels emitted $76 \mathrm{t}$ of mercury into the atmosphere, as shown in figure $5^{4}$. Almost 87 percent or $66 \mathrm{t}$ originated from the burning of coal. The single largest point source of anthropogenic mercury emissions is coal-fueled utility boilers used for electrical generation. Recovery of mercury presents a problem because it is present in coal in very small quantities, but the enormous amount of coal burned produces a large overall contribution. Oil and gas combustion, mainly in business and residential boilers and furnaces for space heating, emitted $10 \mathrm{t}$ of mercury into the air. The concentration of mercury in oil and gas is even less than in coal. Oil and gas burners are widely dispersed, small, and the stacks are generally uncontrolled. Various types of waste combustors and incinerators ${ }^{5}$ emitted $54 \mathrm{t}$ of mercury into the atmosphere in 1996. Two principal contributors were municipal waste combustors (27 t) and medical waste incinerators (15 t). Mercury additions to both municipal and medical wastes have been reduced, mainly by eliminating the use of mercury-containing batteries by mandate, and by the use of a new class of electronic medical instrumentation to replace those that formerly required mercury, for example, medical thermometers and blood pressure gauges. Hazardous waste (solid and liquid) was burned both in hazardous waste combustors and cement kilns. These sources emitted $11 \mathrm{t}$ of mercury into the atmosphere in 1996.

\footnotetext{
${ }^{4}$ Figure 5 is an update of figure 6, "Domestic flow of mercury in 1990" (Jasinski, p. 24). Both figures address supply, demand, and emissions to the environment. For a detailed explanation of figure 5 flow amounts and how they were derived, see pages $55-58$ in the Appendix. For the purposes of this analysis, it is assumed that all flow amounts are 100 percent mercury.

${ }^{5}$ The terms "incinerator" and "combustor" have no technical differences and are incorporated in this report to follow historical usage.
} 


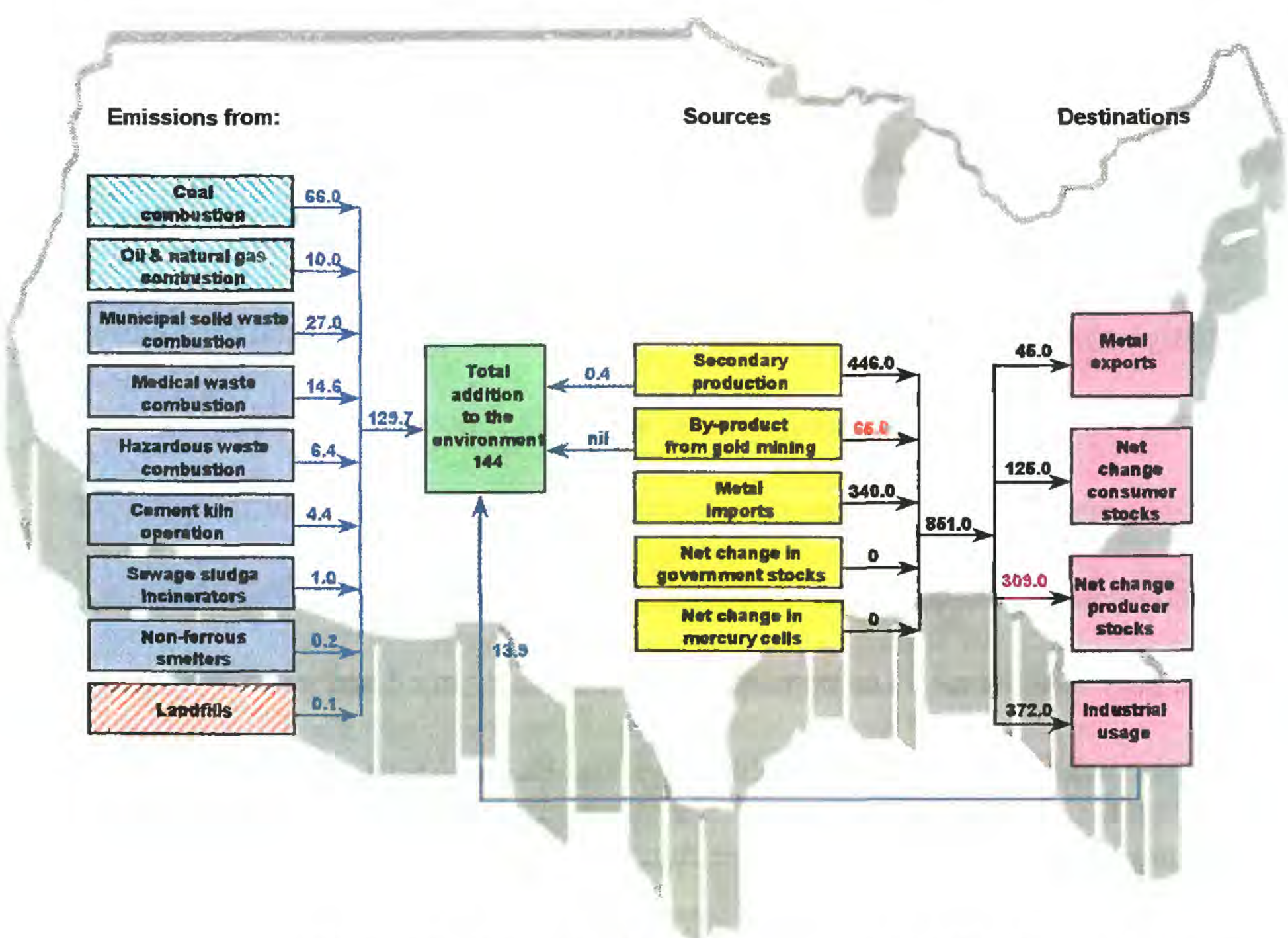

Figure 5. Domestic flow of mercury in 1996, in metric tons.

Several factors are at work to reduce the total mercury emission levels from these sources.

These factors include mandated stack emission controls, similar to those for municipal and medical waste combustors; and closure of hazardous waste combustors that had been justified by subsidies to the combustors for co-generated electricity. Finally, although hazardous waste can be utilized in cement kilns, its use limits production, because the fuel value of the waste is variable and its use requires more control. During periods of high capacity usage, cement kilns run on conventional fuels.

A total of $144 \mathrm{t}$ of mercury entered the U.S. environment from all anthropogenic sources in 1996. This is 35 percent of the total mercury entering otherwise useful applications (417 t). A significant amount of mercury, about $13.9 \mathrm{t}$, entered the environment from spills, breakage, and other leaks as mercury was used. Comparison of figures 5 and 6 indicates that mercury mine closures in the early 1990 's were responsible for a significant reduction of mercury releases to the 
environment (78 t) from the milling and roasting of mercury ores. Domestic mercury releases to the environment in 1996 decreased by $97 \mathrm{t}$ over 1990 levels, that is, $144 \mathrm{t}$ (1996) versus $241 \mathrm{t}$ (1990). Mercury releases from incineration decreased by 47 percent (100 to $53 \mathrm{t}$ ) from 1990 to 1996. This reduction took place because of fewer mercury-containing products entering waste streams and more efficient stack emission controls on incinerators. Mercury disposed of in landfills, excluding soil amendments, ${ }^{6}$ in 1996 (295 t) was 61 percent less than in 1990 (755 t).

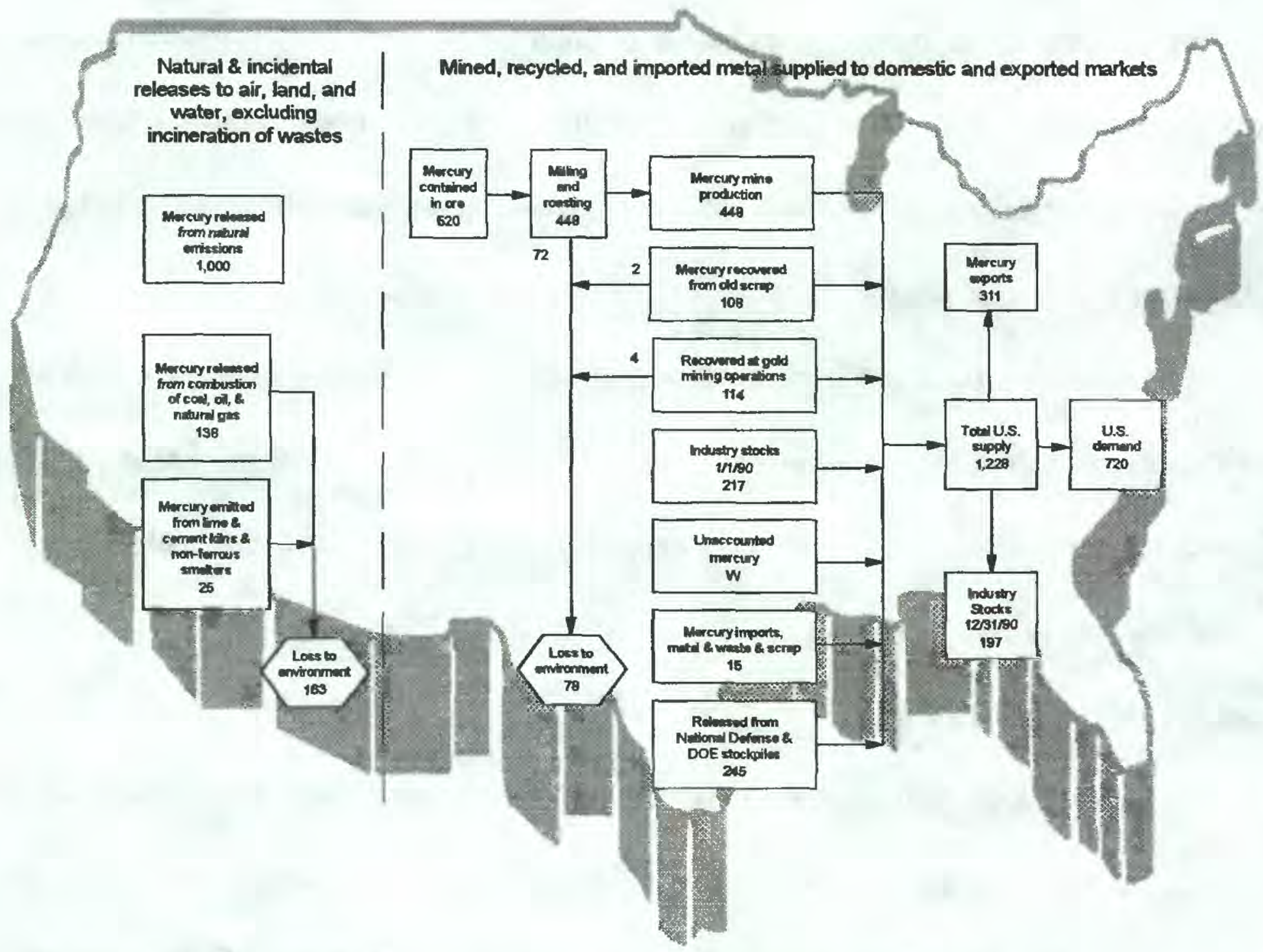

Figure 6. Domestic flow of mercury in 1990, in metric tons (Jasinski, 1994): natural and incidental releases, and mined, recycled, and imported metal supplied to domestic and exported markets. $\mathrm{W}$, withheld.

\footnotetext{
${ }^{6}$ Sewer treatment plant sludges are applied to soils as fertilizers. Such sludges contain nutrient minerals, but also traces of heavy metals, including mercury.
} 


\section{Sources - 1996}

As shown in figure 5, U.S. mercury sources in 1996 included secondary production (446 t), by-product from gold mines ( $65 \mathrm{t}$ ), and mercury metal imports (340 t). These sources contributed $851 \mathrm{t}$, exceeding metal exports of $45 \mathrm{t}$, and reported consumption of $372 \mathrm{t}$ by a total of $434 \mathrm{t}$. The $434 \mathrm{t}$ represent an increase of consumer stocks of $125 \mathrm{t}$, and an increase of producer stocks of $309 \mathrm{t}$. Secondary production of mercury, by itself, was greater than reported mercury industrial usage in the United States in 1996.

In 1996, no government stockpile sales or chlor-alkali mercury-cell closures took place, so no mercury entered the economy from those particular sources. Although there is little reason for government stockpile sales in the near term, future market disruptions can be expected as occasional mercury-cell closures occur within the chlor-alkali industry.

The chlor-alkali industry uses mercury-containing electrolysis cells as one technology to produce chlorine from chloride salts of sodium or potassium. Approximately $3,000 \mathrm{t}$ of mercury resides in this mercury cell stock. Mercury cell chlorine plants are slowly being phased out in favor of non-mercury technologies.

\section{Sources - 1990 Versus 1996}

In 1996, secondary production ( $446 \mathrm{t}$ ) was more than four times the level of secondary production in 1990 (mercury recovered from old scrape, fig. 6). Although no domestic, primary mine production of mercury occurred in 1996, $448 \mathrm{t}$ was produced from U.S. mercury mines in 1990. The change from primary mine production to increased secondary production over the 6year period is important because it eliminated a major source of mercury to the environment, approximately $72 \mathrm{t}$ from milling and roasting, probably reflecting increased recovery efforts due to 
legislation. Currently, much of the recycling occurs in States that encourage and support recycling (see table 1).

From 1990 to 1996, there was a total trade turnaround of $591 \mathrm{t}$, indicating a growing dependence on foreign sources for the current mercury needs of the United States. Production of mercury, as a by-product of gold mining operations, decreased from $114 \mathrm{t}$ in 1990 to $65 \mathrm{t}$ in 1996, ' a 43 percent decrease. Imports of mercury rose sharply from $15 \mathrm{t}$ in 1990 to $340 \mathrm{t}$ in 1996 . On the other hand, mercury exports decreased dramatically from $311 \mathrm{t}$ in 1990 to $45 \mathrm{t}$ in 1996.

Compared to 1990 , when the U.S. Government stockpile released $245 \mathrm{t}$ of mercury to the market, 1996 saw no such sales. Sales were suspended in 1994 pending the release of the Mercury Study Report to Congress (U.S. Environmental Protection Agency, 1997b), and have not resumed as of this writing (1999).

\section{Disposition - 1996}

Figure $7^{7}$ illustrates that in $1996,372 \mathrm{t}$ of mercury flowed into private stocks. Private stocks are mercury residences that are nongovernmental stockpiles. They are controlled by producers of mercury metal, manufacturers of products containing mercury, users of mercury in other production processes (such as chlor-alkali plants), retail consumers, wholesale distributors, and scrap brokers. Private stocks include inventories (for example, ores and scrap, work-inprogress inventories, inventories for sale) and products in use (such as dental fillings, switches, fluorescent lamps). In 1996, $794 \mathrm{t}$ flowed out of private stocks, of which 56 percent went into secondary production to be recycled and returned to useful applications. The balance, 44 percent, either was disposed into landfills (295 t), or was lost to the air from incineration processes (53 t).

\footnotetext{
${ }^{7}$ Figure 7 is an update of figure 8, "Domestic flow of mercury in 1990 - continued", (Jasinski, 1994, p. 25). Both figures address U.S. industrial inflows and outflows. For a detailed explanation of figure 7 flow amounts and how they were derived, see pages 59-69 in the Appendix.
} 
The total unrecovered mercury (lost during incineration or to landfills) of $348 \mathrm{t}$ represents a private stock-wasting rate of 5 percent in 1996.

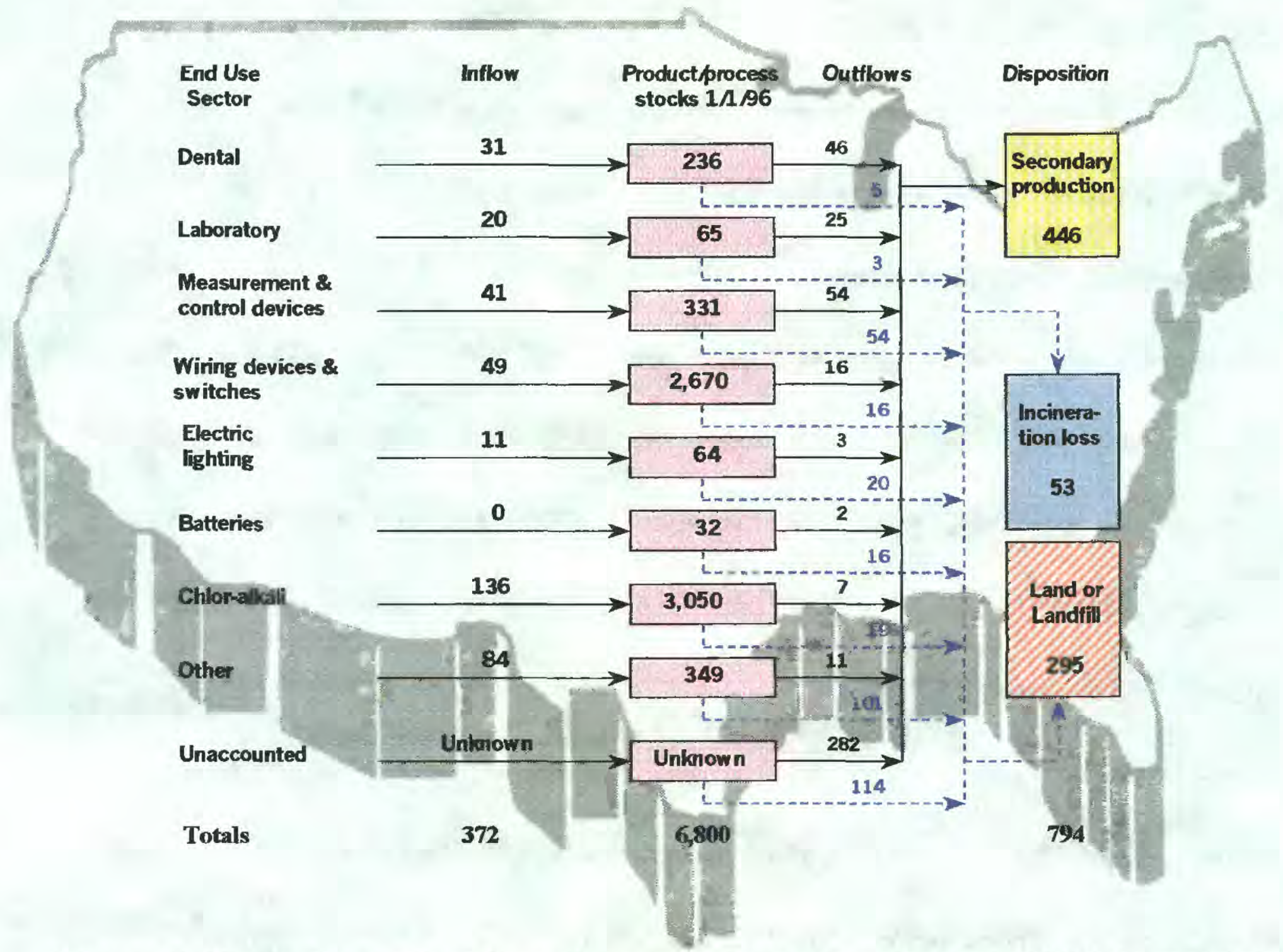

Figure 7. Domestic product flow of mercury through end uses in 1996, in metric tons.

The majority of the private mercury stock was split between (1) chlor-alkali plants (45 percent), at 14 locations, and (2) wiring devices and switches (39 percent), widely dispersed in virtually every facet of the economy. Should these mercury-cell chlor-alkali plants close, most of the associated mercury stocks could be easily recovered. On the other hand, recovery of the mercury held in electrical devices would be much more problematic, although in some States, such as Minnesota, companies like Honeywell offer a free recycling program for mercurycontaining thermostats (CREST, 1995). 
The chlor-alkali industry used $136 \mathrm{t}$ of mercury in 1996, almost triple the mercury usage in the next category, wiring devices and switches (49 t). Except for the chlor-alkali plants, and wiring devices and switches, which together make up 84 percent of private mercury stocks, all other private stocks had larger outflows of mercury in 1996 than inflows.

At the beginning of 1996, private stocks totaled $6,800 \mathrm{t}$ of mercury, exceeding all U.S. Government mercury stockpiles of $4,600 \mathrm{t}$. Together, these private sector and government stocks $(11,400 t)$ represent approximately a 27 -year supply of mercury at the $417 \mathrm{t}$ level of industrial and exported demand in 1996.

\section{Disposition - 1990 Versus 1996}

A nearly 50 percent reduction in total mercury flows to industry occurred between 1990 and 1996. The mercury flows to industry went from $711 \mathrm{t}$ in 1990 to $372 \mathrm{t}$ in 1996. Comparing figure 7 with figure 8, mercury flowing into all specified industrial sectors in 1996 was lower than 1990 levels: dental 30 percent; laboratory 38 percent; measurement and control devices 62 percent; wiring devices and switches 30 percent; lighting 66 percent; batteries 100 percent; and chlor-alkali plants 45 percent.

Excluding the chlor-alkali industry's private mercury stocks, which were not estimated in the 1990 report, the sum of all other private stocks decreased from 4,300 $t$ in 1990 to $3,800 \mathrm{t}$ in 1996, a compound annual stock reduction rate of slightly more than 2 percent.

In 1990, the paint sector was still adding mercury to water-based paints, mainly as a fungicide. In 1996, this sector does not appear because mercury-containing paints were banned from the market by legislation in 1992. In 1990, mercury-containing dry cell batteries used $105 \mathrm{t}$ of mercury; in 1996, virtually no mercury went to dry cell batteries because of both legislation and technological advances. 


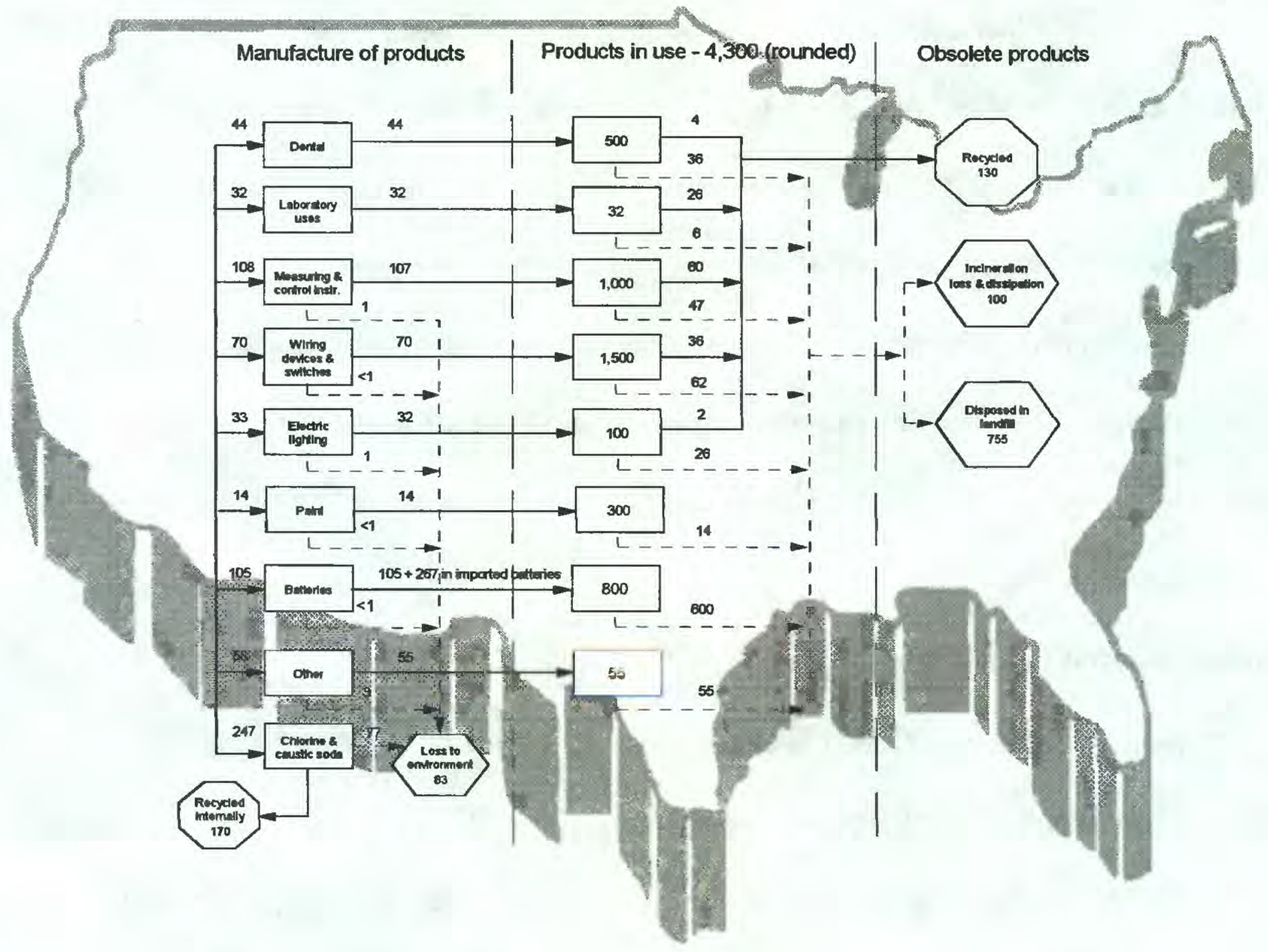

Figure 8. Domestic flow of mercury in 1990, in metric tons (Jasinski, 1994): products manufactured, in use, and obsolete.

\section{Case Study - Chlor-alkai}

Since 1989 , the use of mercury for the production of chlorine and caustic soda (37 percent of total mercury consumption in 1996) has been the largest component of U.S. mercury consumption. Mercury is used in electrolytic cells (mercury cells) to decompose chloride compounds. During this process, small amounts of mercury are emitted to the air, water, and land as sludge and as wastewater. A detailed description and a flow diagram of this process are included in Information Circular 9412 (Jasinski, 1994). Because mercury cells (a mature technology) account for a major part of total industrial usage of mercury, a more detailed look at the flow of mercury within this process is warranted. 
The chlor-alkali industry employs three classes of stocks (inventories) that are shown in figure $9^{8}$. They include new purchases or make-up (averaging about $150 \mathrm{t}$ per year during the 1990 's) that are held in warehouses to be used to restore any losses from the process; an average mercury inventory (134t) passing through the recycling processes within the plants; and an average mercury inventory cycling through mercury cells $(2,770 t)$.

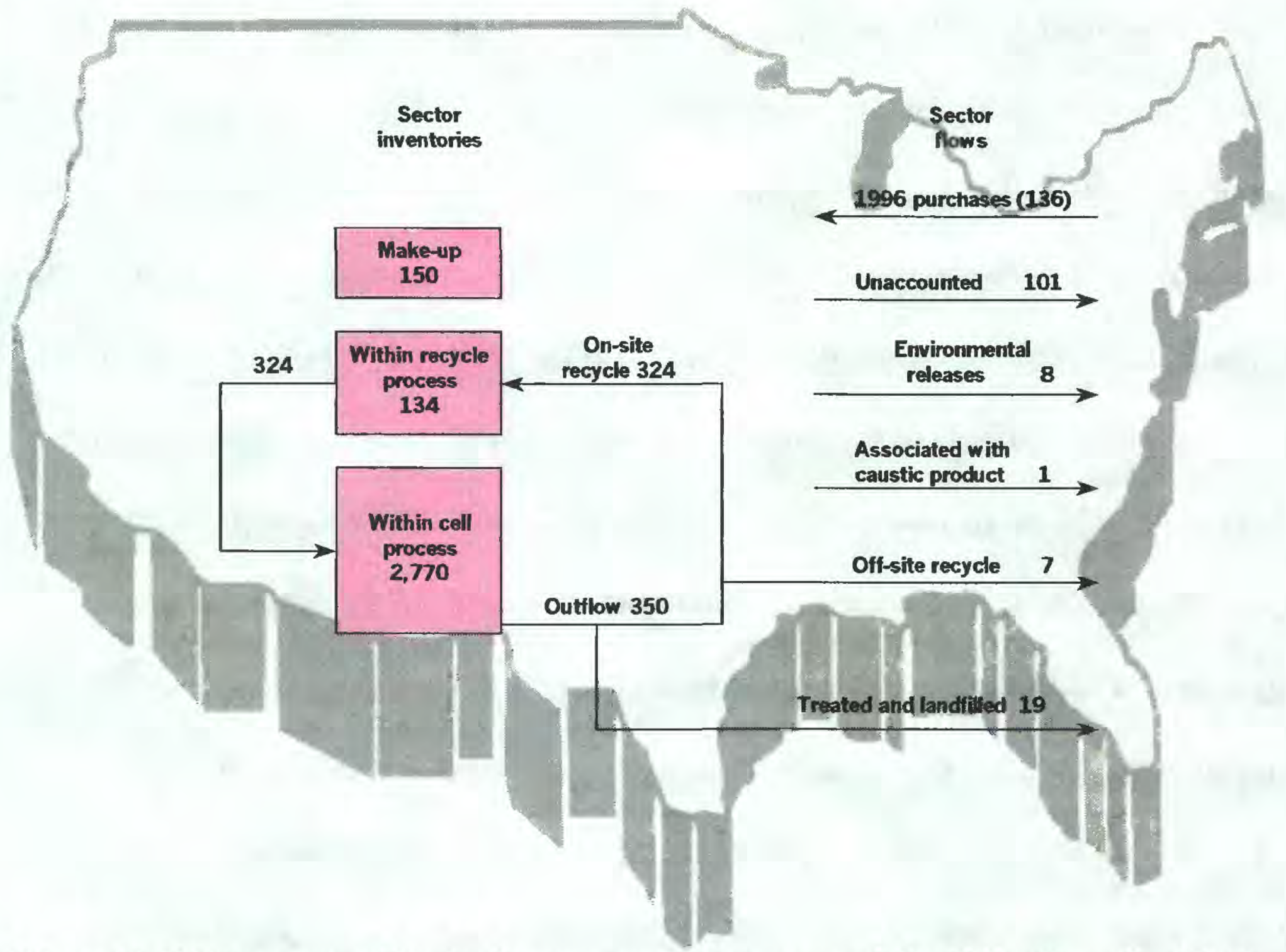

Figure 9. 1996 mercury flow in the mercury cell process of the U.S. chlor-alkali industry, in metric tons.

In 1996, Toxic Release Inventory data (1997) indicated ${ }^{9}$ that the chlor-alkali industry released approximately $8.0 \mathrm{t}$ of mercury directly to the environment ( $7.6 \mathrm{t}$ to air, $0.2 \mathrm{t}$ to land, 0.2 $\mathrm{t}$ to water), $7 \mathrm{t}$ to off-site recyclers, and $19 \mathrm{t}$ to landfills. Less than $1 \mathrm{t}$ is associated with the

\footnotetext{
${ }^{8}$ Figure 9 (1996) and figure 10 (1990) represent inflows and outflows in the domestic chlor-alkali industry. For a detailed explanation of how they were derived, see pages 70-71 in the Appendix.

${ }^{9}$ All chlor-alkali plants operating mercury cells reported except for one minor plant in Vicksburg, Miss.
} 
caustic product that leaves the plant, most likely distributed to paper mills. Subtracting these known losses of $35 \mathrm{t}$ from the given 1996 purchase of $136 \mathrm{t}$ of mercury by the industry leaves a total of unaccounted mercury in 1996 of $101 \mathrm{t}$. In 1999, the "missing" mercury continues to be the subject of intense scrutiny by the industry and the EPA (F. Anscombe, EPA, oral commun., May 7, 1999).

Comparing figure 9 (1996) with figure 10 (1990), reveals several trends: There were four more mercury cell chlor-alkali plants operating in 1990 than in 1996, and the incremental mercury inventory of the chlor-alkali industry to support those plants was $544 \mathrm{t}$. Mercury purchases by the chlor-alkali industry in 1990 amounted to $247 \mathrm{t}$, which were $111 \mathrm{t}$ more than in $1996(136 \mathrm{t})$. The industry landfilled $41 \mathrm{t}$ less mercury in 1996 (19 t) than in $1990(60 \mathrm{t})$, a 68 percent decrease. Releases and losses embodied in caustic product remained about the same. In 1990, the private stocks held by the chlor-alkali industry were approximately $3,600 \mathrm{t}$. These stocks had been reduced in 1996 to $3,050 \mathrm{t}$. This difference is an overall decrease of 15 percent, or about 2.5 percent per year. This inventory reduction for mercury cells most likely flowed out of the United States as exports, and is part of the negative trade balance in 1991 and 1992 (fig. 2).

The chlor-alkali industry has been closing some mercury cells and tightening mercury flow controls on the remaining operational cells. No new mercury cell plants are being constructed. New, more efficient, and less costly technologies have been available for a long time, and they are being installed where new chlorine capacity is needed. However, some very efficient, largecapacity mercury cell operations still exist and will remain operational into the foreseeable future. 


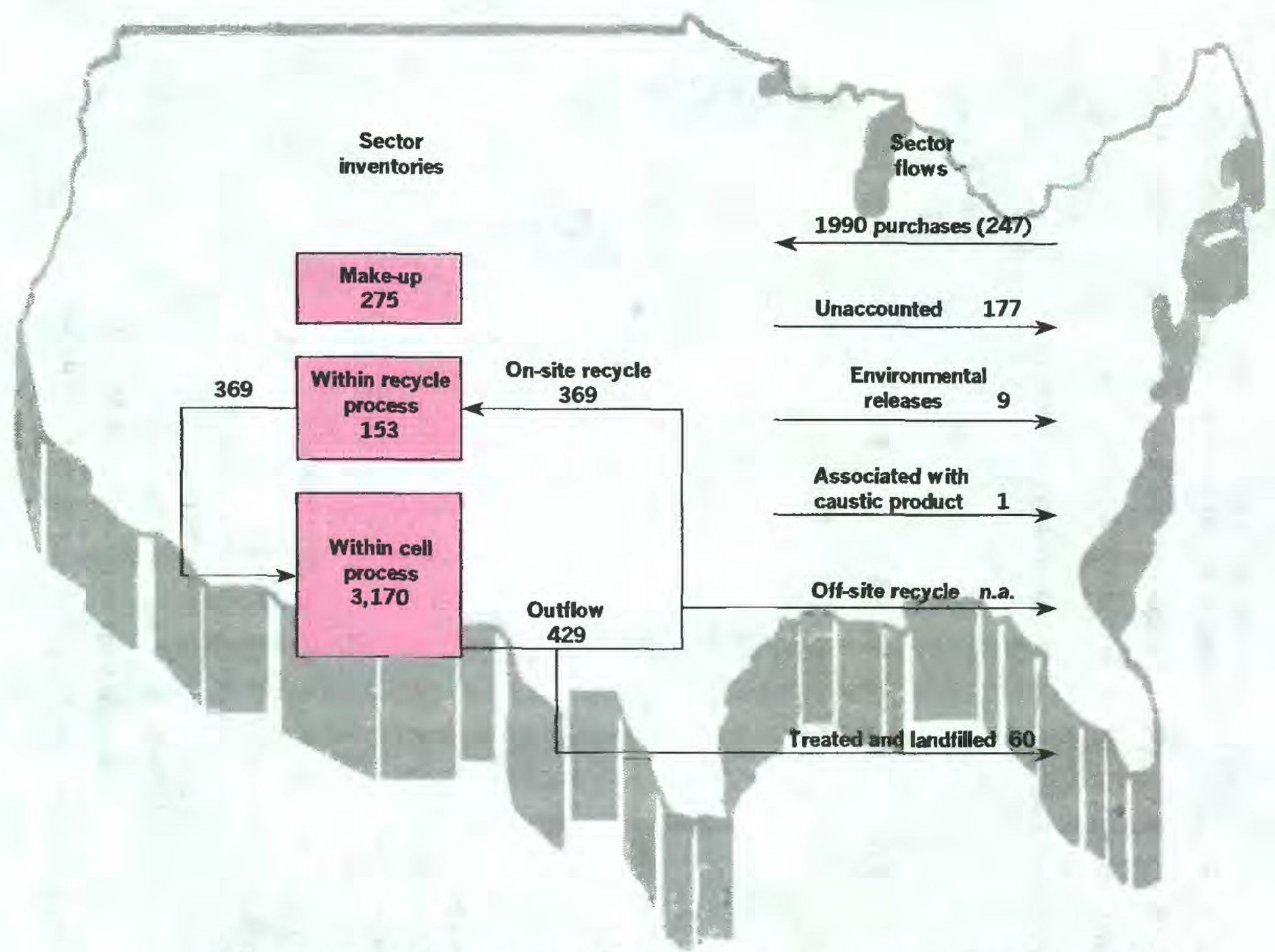

Figure 10. 1990 mercury flow in the mercury cell process of the U.S. chlor-alkali industry, in metric tons; n.a., not applicable.

\section{Legislation}

Figure 11 illustrates time series for mercury reported consumption, production, and price alongside dates of regulatory and control legislation. Even though numerous regulations are in place, Federal and local governments are implementing new actions to further reduce mercury contamination of the environment from all anthropogenic sources and to limit the use and disposal of mercury. Recently established regulatory actions could reduce mercury emissions from municipal and medical waste about 90 percent by the year 2000 , when proposed rules become effective. Table 1 lists legislation and programs that have affected mercury flows in the 1990's. 


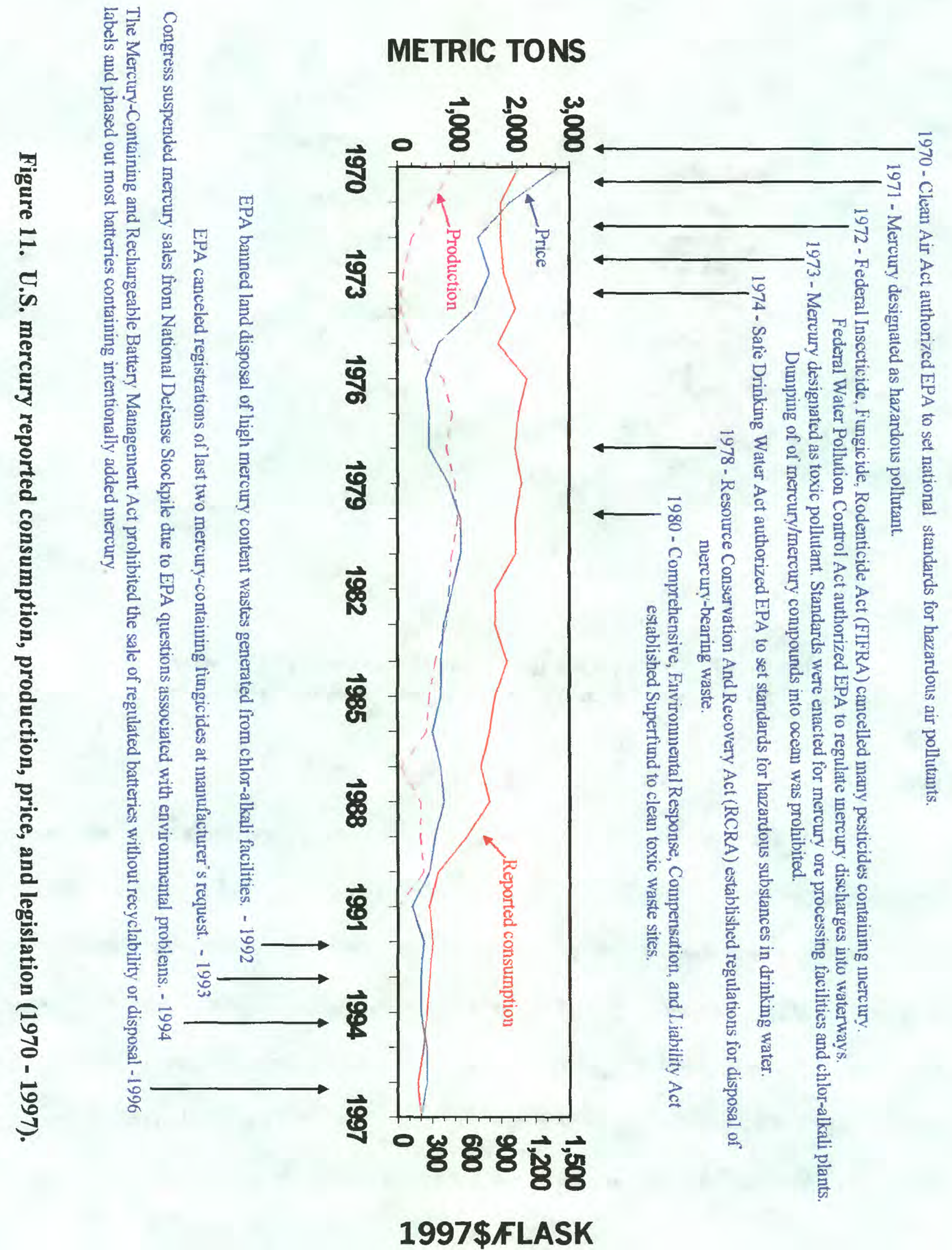

๙ 
Table 1. Legislation and programs affecting mercury.

\begin{tabular}{|c|c|c|}
\hline Year & Authority & Summary \\
\hline 1992 & EPA $\ldots \ldots \ldots$ & $\begin{array}{l}\text { Banned the land disposal of high mercury content wastes that are } \\
\text { generated from the electrolytic production of chlorine and caustic } \\
\text { soda. (effective } 5 / 8 / 92 \text { ). }\end{array}$ \\
\hline 1992 & New Jersey $\ldots . . . .$. & $\begin{array}{l}\text { Restricted the sale and disposal of batteries containing mercury. } \\
\text { Banned the sale of products that have cadmium, mercury, or other } \\
\text { toxic materials in packaging after } 1 / 1 / 93 \text {. }\end{array}$ \\
\hline 1992 & California and Minnesota ..... . & Placed restrictions on the disposal of fluorescent light tubes. \\
\hline 1993 & EPA $-\ldots \ldots \ldots$ & $\begin{array}{l}\text { Canceled the registrations for the last two mercury-containing } \\
\text { fungicides approved for use in the United States at the request of } \\
\text { the manufacturer. Cancellation became effective } 11 / 1 / 93 \text {. }\end{array}$ \\
\hline \multirow[t]{2}{*}{1993} & Florida $-\ldots$ & $\begin{array}{l}\text { Approved emissions regulations for resource recovery plants to } \\
\text { limit stack emissions of mercury. } \\
\text { Limits the release of mercury to the environment from the disposal } \\
\text { of batteries. }\end{array}$ \\
\hline & $\begin{array}{l}\text { Arkansas, Minnesota, and New } \\
\text { Jersey. }\end{array}$ & $\begin{array}{l}\text { Banned the sale and distribution of mercuric-oxide button cell } \\
\text { batteries. }\end{array}$ \\
\hline \multirow[t]{3}{*}{1994} & U.S. Food and Drug Administration & $\begin{array}{l}\text { Set level of } 1 \text { part per million in fish as the safe maximum limit } \\
\text { for human consumption. Several States, primarily in the } \\
\text { Northeast, issued warnings against eating freshwater fish because } \\
\text { of elevated levels of mercury. }\end{array}$ \\
\hline & Minnesota - - & $\begin{array}{l}\text { Prohibited the disposal of thermostats and other mercury- } \\
\text { containing devices unless the mercury was removed. }\end{array}$ \\
\hline & Congress - & $\begin{array}{l}\text { Suspended sales from the National Defense Stockpile because of } \\
\text { questions raised by the EPA as to the potential environmental } \\
\text { problems associated with the release of mercury effective } 7 / 94 \text {. }\end{array}$ \\
\hline 1995 & 33 States - & $\begin{array}{l}\text { Issued freshwater fish consumption advisories because of elevated } \\
\text { levels of mercury contamination. }\end{array}$ \\
\hline \multirow[t]{2}{*}{1996} & Public Law 104 - 142 - - & $\begin{array}{l}\text { The Mercury-Containing and Rechargeable Battery Management } \\
\text { Act of } 1996 \text { was made law on May } 13,1996 \text {. Title I prohibited the } \\
\text { sale of regulated batteries after May } 1997 \text { without a label } \\
\text { indicating recyclability or proper disposal. Title II phases out the } \\
\text { use of alkaline-manganese and zinc-carbon batteries containing } \\
\text { intentionally added mercury and button cell mercuric-oxide } \\
\text { batteries. }\end{array}$ \\
\hline & U.S. Coast Guard - . . - - - & $\begin{array}{l}\text { Signed an agreement with the Georgia Environmental Protection } \\
\text { Division to remove from Georgia's waterways discarded zinc-air } \\
\text { batteries containing mercury. }\end{array}$ \\
\hline \multirow[t]{2}{*}{1997} & $\begin{array}{l}\text { EPA, U.S. Department of Justice, } \\
\text { U.S. Attorney for Arizona. } \\
\text { EPA }\end{array}$ & $\begin{array}{l}\text { Settled lawsuit brought by Defenders of Wildlife. The suit was } \\
\text { concerned with mercury pollution of certain Arizona waterways. } \\
\text { Released its } 1996 \text { summary of State-issued warnings to the public } \\
\text { to avoid or limit eating fish from certain water bodies } \\
\text { (Environmental Protection Agency, 1997b). }\end{array}$ \\
\hline & EPA $\cdots$ & $\begin{array}{l}\text { Issued its report on mercury (Environmental Protection Agency, } \\
\text { 1997c) fulfilling the requirements of section } 112(\mathrm{n})(\mathrm{l})(\mathrm{B}) \text { of the } \\
\text { Clean Air Act as amended in } 1990 \text {. }\end{array}$ \\
\hline
\end{tabular}




\section{Outlook}

The following are examples of current actions and efforts to curtail the use of mercury in any nonessential and (or) substitutable application:

- The Chlorine Institute (Report to EPA, 1998) has committed to a 50 percent reduction of mercury used in the chlor-alkali industry by 2005 . This will initially occur through tighter controls over mercury cycling within mercury-cell plants, and eventually, the closing of these plants will shift large private stocks into the market supply line.

- Under the Clean Air Act, EPA has established mercury emissions limits (1) for municipal waste combustors, which should result in a 90 percent decline from 1990 levels by 2000 , and (2) for medical waste incinerators, which should result in a 95 percent decline from 1990 levels by 2002 .

- The EPA and the American Hospital Association agreed to establish several goals regarding waste management, one of which would eliminate specific mercury-containing waste by the year 2005 .

- The EPA's Mercury Study Report to Congress (U.S. EPA, 1997b) predicted that high deposition rates of anthropogenic mercury (from both global and domestic sources) will occur in the Great Lakes Region. The major factors contributing to this phenomenon are proximity to sources and local climate. The increasing concern regarding mercury contamination within the Great Lakes Basin was the impetus for an international agreement between the Governments of Canada and the United States. The agreement sets a goal to significantly reduce the human use and release of mercury from anthropogenic sources in the Great Lakes Basin by 2006. 


\section{International}

Mercury presents a global issue because emissions from identifiable point sources, wherever they are located, find their way into water and air for transport across national borders. Legislation and regulation have been created in many countries to address the mercury issue and are responsible for dramatic decreases in mercury use, and consequently in the available supply of mercury-containing products. As a current, net importer of mercury, the United States must consider the importance of the international flow of mercury, because all of the producing mercury mines are foreign; 86 percent of the mercury cells of the worldwide chlor-alkali industry is outside of the United States; there is a large global trade in mercury $(2,037 \mathrm{t}$ in 1990 and 1,395 $\mathrm{t}$ in 1996); and environmental regulations are not uniform or similarly enforced from country to country.

\section{Emissions to the Environment}

There are several specific international environmental questions regarding mercury. Because People's Republic of China (PRC) is the largest combustor of mercury-containing coal as well as being the largest importer of mercury in the world, what are the internal Chinese flows of mercury and their associated emissions? What are the impacts of the unchecked use of mercury by artisanal miners in Brazil, Ghana, Venezuela, Philippines, and other countries? Are the mercury-emission control levels adequate in foreign chlor-alkali plants? What are the environmental consequences of mercury production in Tajikistan, Kyrgyzstan, and the Ukraine, considering the uncertainties surrounding the poor level of environmental controls within the former Soviet Union (FSU)? Although these questions cannot be answered here, the following anecdotal evidence addresses the concerns. 


\section{By Countries}

\section{Brazil}

The Kayapo Indian Area is situated in the south of the State of Para, Brazil. A study by Antonio Barbosa, a chemist from the University of Brasilia, has confirmed that newborn Kayapo children suffer from high levels of mercury contamination - although not to a sufficiently high degree to yield classic mercury poisoning symptoms (as reported by Cimi - Indianist Missionary Council, 1998). The study showed that mercury levels in Kayapo women drop significantly during pregnancy as the mercury is transferred from the mother and accumulates in the fetus. For this reason, newborn children have higher levels of mercury concentration than their mothers.

\section{Germany}

As reported by Drozdiak (1996), the Rhine River was considered the "sewer of Europe." for decades. Originating in the Alps, the continent's busiest waterway absorbed pesticides from the Swiss chemical factories, potassium salts from Alsatian mines, and heavy metals from German industry. By 1970, mercury and cadmium concentrations had reached very high levels. However, in 1995, French biologists found that salmon and sea trout had returned to the upper Rhine for the first time in 50 years. Lead, mercury, and dioxin levels have been cut by 70 percent since 1986 when an international commission was created to clean up the river

\section{Japan}

According to Takeuchi (1960), effluent containing mercury from an acetaldehyde manufacturing plant was discharged into the small bay of Minamata, Japan. This discharge continued from the years before 1953, when Minamata disease began to occur, to September 1958. A total of 121 cases of Minamata disease were identified in adults, children, and fetuses. About half of the adults, one-third of the children, and about one-eighth of the fetal victims died. Characteristically, the 
children and adults had eaten a great amount of fish and shellfish that contained a considerable amount of mercury. From $1 \mathrm{ppm}$ to $50 \mathrm{ppm}$ were detected in some organs on a wet weight basis. In fetal cases, all of the mothers had eaten large amounts of seafood and river fish. This provided evidence that alkyl mercury penetrates the placental barrier in humans.

In 1959, when the causative agent of the disease was found to be organic mercury, the mud of Minamata Bay was correspondingly found to contain an extremely large amount of mercury. The maximum concentration (133 ppm to 2,010 ppm) was found near the drainage channels from the chemical plants. This Japanese experience served to focus world attention on mercury emitted to the environment.

\section{New Guinea}

Morgan (1995) reported that the gold workings at Porgera, New Guinea, have been operational since 1990. In that time they have yielded more than 6 million ounces of gold, dumping about 40,000 cubic meters of treated tailings into the Porgera River each day. In tests conducted by Phillip Sherman, University of Tasmania, Australia, mercury concentration in the river water was 64 times pre-mining levels.

\section{Russia}

In January 1995, the Arkhangelsk Pulp and Paper Combine of Novodvinsk, Russia, emitted as much as $16 \mathrm{t}$ of mercury compounds into the Svernaya Dvina River (as reported in The Environmental Database [TED Case 245, 1997]). The silt beds of the Svernaya Dvina River were found to contain high levels of mercury salts. Contamination levels were more than 600 times allowable concentration limits. Although the contamination was quickly taken away by high water levels and a strong current to the White Sea (considered to be critical Arctic habitat), the pulp and paper combine continues to emit mercuric substances to the river. The plant is the principal employer in the town, and its water 
treatment plant serves as the water treatment for the community as well as the plant, so it would be very difficult to shut down for necessary improvements.

\section{Tajikistan}

In Tajikistan, the Shing-Mangianskaya mountain range contains many antimony-mercury, goldsulfides, and gold-rare metal mines (as reported by Baratov and Skochilov, 1996). Wastes from these mines as well as natural background materials from these mines have contributed large quantities of mercury and other metals to the Zeravshan River. In the Iskanderkul-Yagnobsky region of that range, which largely specializes in mercury-antimony mining, two areas are notably polluted with mercury, antimony, arsenic, lead, and possibly thallium. The largest area consists of the Jijikrut mine and the Anzob Processing Facility situated in the middle stretch of the Yagnob River. This mine and its processing facility have been operational for more than 30 years. During this period, several million metric tons of mercury-antimony mining waste have been accumulated and occasionally washed into the river. In the second area, around the Konchoch-Skal mine, several hundred thousand metric tons of mercury-antimony waste have accumulated, and considerable amounts have washed into the Konchoch River.

\section{By Processes}

\section{Artisanal Gold}

Artisanal small-scale gold mining of placer deposits occurs mostly in developing countries.

Examples include: Brazil, Venezuela, Colombia, Guyana, and Suriname, which border the Guyana Shield in South America; the Philippines and New Guinea in Oceania; and Nicaragua in Central America.

In Brazil, the amount of mercury entering the environment was estimated at about $200 \mathrm{t} / \mathrm{yr}$ [Trade and Environment Database (TED) case 132]. As described in TED case 132, gold recovery is performed by removing sediments from river bottoms and adjacent areas and feeding them through a 
number of mercury-coated sieves. The mercury amalgamates with the gold in the sediments, separating the gold from the rest of the material. Considerable amounts of mercury remain in the gold-depleted soil, and much of this finds its way into the rivers. The gold-mercury amalgam is then retorted. Heat drives off the mercury, leaving the gold product. While most of the mercury condenses and is recovered, some of this mercury is emitted to the air, where it resides for a time before being deposited on nearby land or water surfaces through precipitation. Mercury deposited on land ultimately reaches streams and rivers through runoff. Roughly 1.0 kilograms of mercury enter the environment for every kilogram of gold produced by artisans (Farid and others, 1991). Another estimate according to research by Veloso de Araujo (1995), in the Alta Floresta area, State of Mato Grosso, Brazil, was that a typical month's gold production of 230 kilograms $(\mathrm{kg})$ emitted $240 \mathrm{~kg}$ of mercury to the atmosphere as elemental mercury vapor, and $60 \mathrm{~kg}$ of mercury into rivers.

\section{Coal Combustion}

On a worldwide basis, coal is the most widely used primary fuel, accounting for approximately 37 percent of total fuel used for electricity production (U.S. Department of Energy, 1998). The amount and percentage of global mercury contributions originating from the burning of fossil fuels such as coal are unknown. If the rest of the world parallels the United States with respect to mercury emissions, then coal burning may be the single largest anthropogenic source of mercury to the atmosphere. Although all countries recognize that burning coal can degrade the environment, not all have pursued or are actively implementing methods to significantly reduce emissions.

Canada, most European countries, and Japan are widely recognized as having strict regulations limiting emissions from coal-fired plants. Although these regulations are not specifically targeted at reductions in mercury emissions at this time, some of the emission control technologies currently employed prevent nearly one-half of the mercury contained in coal from being emitted to the 
atmosphere (Chu and Porcella, 1995). As stricter regulations are implemented and as mercury is targeted, mercury contributions to the environment from these sources should decrease.

Some countries, such as PRC, India, Russia, and other countries of the FSU, are taking some measures to reduce emissions from coal burning, but they have not been very effective. Russia, other countries of the FSU, and some other countries in Eastern Europe have actually decreased coalburning, in part because of depressed economies, but also because of substituting natural gas for coal in some utility plants (Mining Journal, 1997). As industrializing countries increase coal burning, but allow pollution controls to lag far behind, emissions to the environment, including mercury, will increase. PRC uses coal to produce nearly 80 percent of its electrical energy. Chinese coal, in general, contains about the same amount of mercury as U.S. coals; however, preliminary studies of coals burned in other countries indicate that mercury can be as much as 10 times higher (Robert Finkelman, USGS, oral commun., 1998). At current growth rates, PRC will continue to be the largest coalburning nation in the world.

A broad estimate of mercury emissions from coal burning could be made. A global study would have to consider average mercury contents and destination of coal shipments, identify significant coal combusting facilities, and identify recovery technologies used. A detailed estimate of global mercury contributions from coal combustion requires collection and analysis of data from individual coal-fired utility plants and industrial boilers throughout the world. The USGS is planning to undertake a study that will collect information and estimate quantities and composition of air pollution produced through coal combustion in the United States. An examination of mercury emissions will be included in that study (Robert Finkelman, USGS, oral commun., 1998). 


\section{Oil and Natural Gas Combustion}

On a worldwide basis, gas and oil are the second and third most widely used primary fuels, accounting for approximately 16 percent and 10 percent of total fuel used for electricity production, respectively (U.S. Department of Energy, 1998). The top five consumers of oil for generating electrical power include the United States, Japan, Russia, PRC, and Germany. Studies have shown that the oil refining process also releases mercury (Akelsson, 1998). Oil burning is a contributor to mercury emissions on a global basis, but much less than coal.

Burning natural gas to generate electricity is not a significant mercury emissions factor on a worldwide basis. In the United States, the mercury emissions rate from burning natural gas is relatively low, contributing approximately 0.1 percent of total U.S. mercury emissions. The net affect of the substitution of natural gas for coal to produce electricity should result in lowering atmospheric loading of mercury. As in the case of coal and oil, data are insufficient to provide an estimate of global mercury emissions from natural gas-fueled plants.

Although the mercury content of natural gas is generally believed to be comparatively low, there are exceptions. Approximately 6-8 $\mathrm{t}$ of mercury is recovered annually from North Sea gases processed in the Netherlands (Maxson and Vonkeman, 1996). High levels of mercury are also known to exist in natural gas burned in Germany, but the mercury is not recovered. These two examples illustrate the need for further research into the small-scale mercury content of natural gas and emissions from its combustion.

\section{Sources}

Presently, the world-class, producing primary mercury mines are located in Algeria, PRC, Kyrgyzstan, and Spain. (Unless noted, the production numbers in this section are from the Gobi Report, 1998 (see Appendix, p. 73)). Before the worldwide collapse of mercury markets in the early 
1990's, Italy, Mexico, Slovakia, Slovenia, and Turkey were all active minor producers. Although none of these countries are presently producing mercury from primary mines, each retains significant reserves.

The Western European region was the world's largest mercury supplier in terms of net trade in $1996(1,141 \mathrm{t})$. Spain, the largest producer within this area, provided 92 percent of this region's total output. The FSU, principally the nations of Kyrgyzstan, Tajikistan, Russia, and Ukraine, was the world's second largest supplier of mined mercury (785 $t$ in 1996). Northeast Asia (PRC, Japan, and Korea) has widely scattered but extensive mercury reserves. In 1996, $508 \mathrm{t}$ of mercury were produced from mines in the PRC. Algeria produced $347 \mathrm{t}$ of mercury from its mines in 1996; this accounted for all of Africa's production.

Some mercury is produced as a by-product of gold production, for example, in Mexico. Mercury is also produced as a by-product of zinc production. Finland started by-product mercury production from zinc operations in 1971 (Roskill Information Services, Ltd., 1990), and produced $88 \mathrm{t}$ in 1996 as reported in the USGS Minerals Yearbook, 1998.

\section{Disposition}

Approximately 40 percent of the mercury produced in 1996 was used in the world's chloralkali industry $(1,344 \mathrm{t})$. Western Europe, with the world's largest reservoir of mercury-cell chloralkali capacity, consumed $631 \mathrm{t}$ of mercury just for that purpose in 1996. North America, Eastern Europe, and India/Pakistan were also significant users of mercury $(136,184$, and $133 \mathrm{t}$, respectively) for chlorine production. North America, Western Europe, and northeast Asia were the principal economies using mercury (a total of $860 \mathrm{t}, 81$ percent of global manufacturing) for the production of mercury-containing goods. 
The international use of mercury for chlor-alkali production decreased for the period 1990 1996 by 33 percent, and for mercury-containing products by 42 percent. Estimated mercury use by small-scale gold miners in Brazil decreased from $200 \mathrm{t}$ in 1990 to $100 \mathrm{t}$ in 1996. Mercury use by gold miners in other developing countries is probably significant based on anecdotal evidence, but is not quantifiable at this time. Stock changes in the world were extensive both in 1990 and 1996 (25 percent of their respective years' production). Besides the United States, Western Europe seems to be the only region that is actively reducing mercury stocks. On the other hand, PRC has apparently been adding mercury to its stockpiles in levels far in excess of their own needs.

Trade, 1990 versus 1996

Major net mercury exporters in 1996 included Western Europe, the FSU, and Africa. Major net mercury importers in 1996 included Asia, Eastern Europe, and South America. These net trade flows to and from various regions of the world are displayed in figure 12, which also illustrates the 32 percent decrease in worldwide mercury trade from 1990 to 1996.

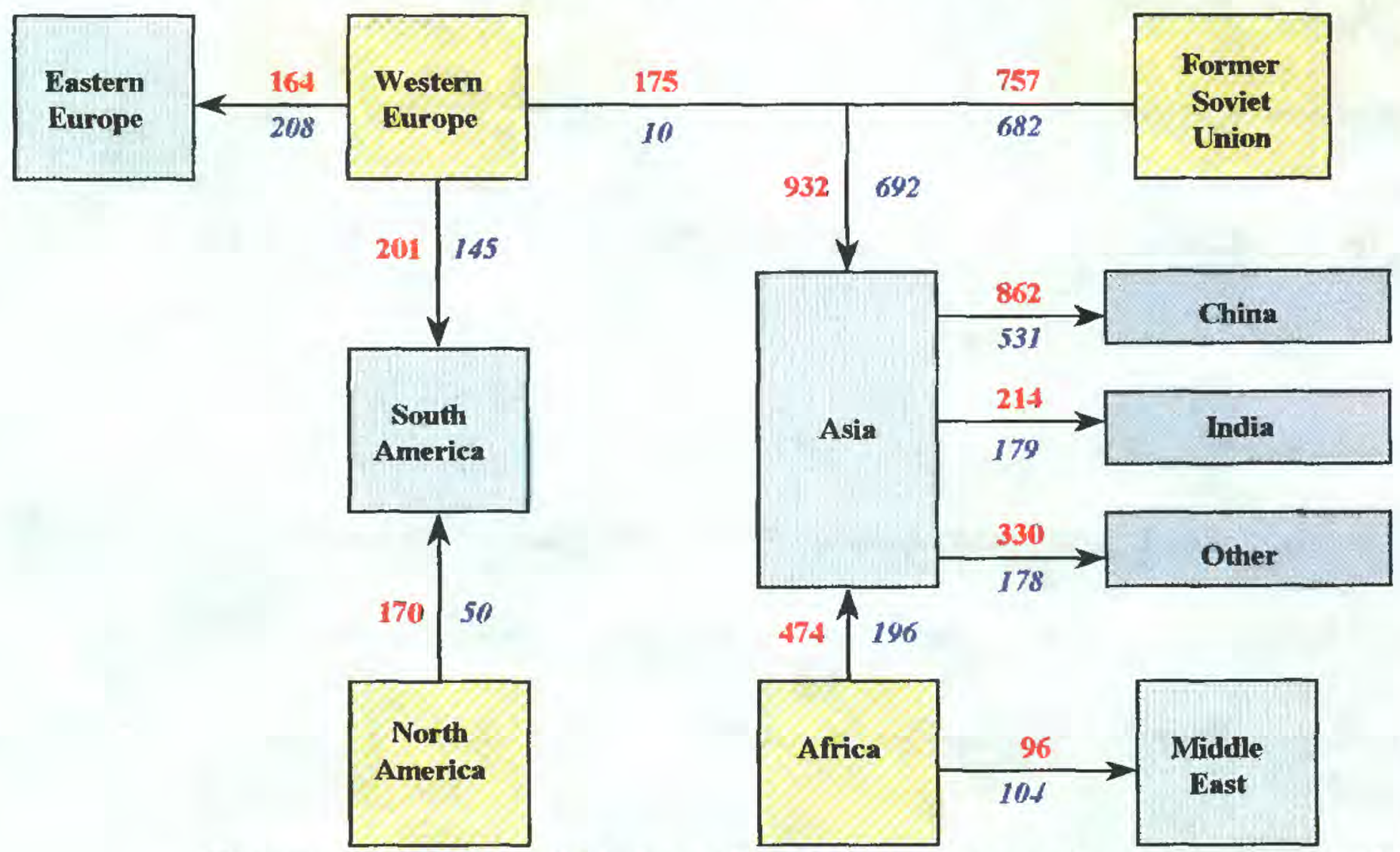

Figure 12. $1990 \mid 1996$ international net mercury trade flow, in metric tons. 
Figure 13 presents a slightly more detailed picture of global mercury demand. Global production of mercury in $1996(3,337 t)$ decreased by 2,019 $t$ (38 percent) over 1990 levels $(5,356 t)$.
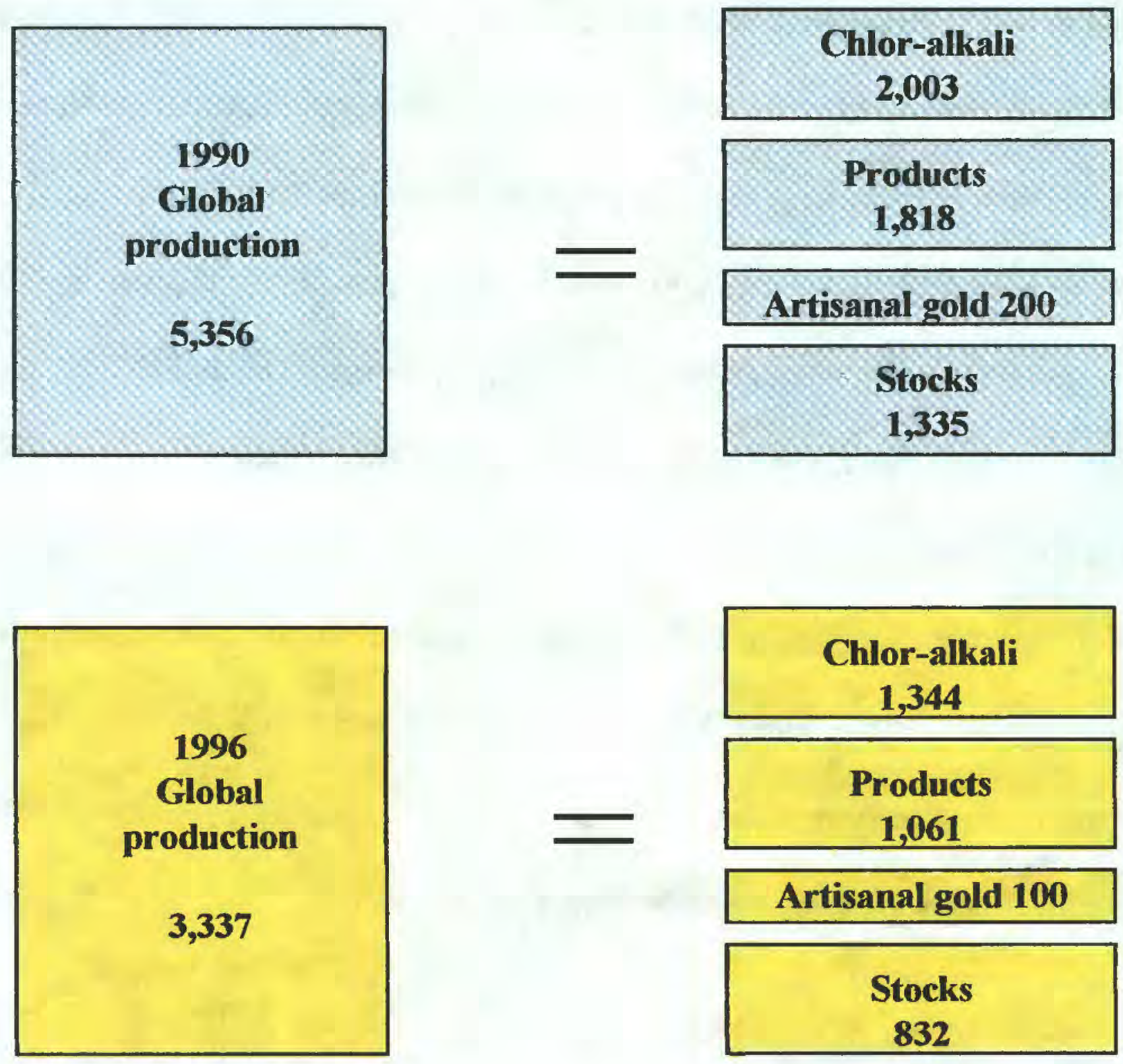

Figure 13. Global mercury flow by use, 1990 versus 1996 , in metric tons.

\section{Case Study - Chlor-alkali}

Table 2 reports data from the Chemical Marketing Association, Inc. (1999) showing 1992 and 1997 world chlorine production capacities. ${ }^{11}$ The following observations can be made:

1. Most of the growth in chlorine capacity is occurring in Asia, including the subcontinent of India.

\footnotetext{
${ }^{11}$ Although prior analyses were based on 1990 and 1996 data, only 1992 and 1997 data were available in this case.
} 
2. Sixty-five percent of mercury cell capacity is located in Europe.

3. Mercury cells as a percentage of total capacity have remained the same or decreased everywhere (only exception is northeastern PRC), that is, decommissioning is occurring and most new capacity is not mercury cell.

Table 2. World chlorine capacity from chlor-alkali plants, in thousands of metric tons.

\begin{tabular}{|c|c|c|c|c|c|c|c|c|c|c|c|}
\hline & $\begin{array}{c}\text { Total } \\
\text { World }\end{array}$ & $\begin{array}{c}\text { North } \\
\text { America }\end{array}$ & $\begin{array}{c}\text { South } \\
\text { America } \\
\end{array}$ & $\begin{array}{c}\text { West } \\
\text { Europe }\end{array}$ & $\begin{array}{c}\text { East } \\
\text { Europe }\end{array}$ & FSU & Africa & $\begin{array}{c}\text { Middle } \\
\text { East }\end{array}$ & $\begin{array}{c}\text { India } \\
\text { Pakistan }\end{array}$ & $\begin{array}{l}\text { N.E. } \\
\text { Asia }\end{array}$ & $\begin{array}{l}\text { S.E. } \\
\text { Asia }\end{array}$ \\
\hline \multicolumn{12}{|l|}{ All Cells } \\
\hline 1992 & $\begin{array}{c}45,394 \\
100 \% \\
\end{array}$ & $\begin{array}{c}13,575 \\
30 \%\end{array}$ & $\begin{array}{c}1,696 \\
4 \% \\
\end{array}$ & $\begin{array}{c}11,223 \\
25 \%\end{array}$ & $\begin{array}{c}1,896 \\
4 \% \\
\end{array}$ & $\begin{array}{c}3,773 \\
8 \% \\
\end{array}$ & $\begin{array}{l}535 \\
1 \% \\
\end{array}$ & $\begin{array}{l}800 \\
2 \% \\
\end{array}$ & $\begin{array}{c}1,523 \\
3 \% \\
\end{array}$ & $\begin{array}{l}9,706 \\
21 \% \\
\end{array}$ & $\begin{array}{l}667 \\
1 \% \\
\end{array}$ \\
\hline 1997 & $\begin{array}{c}49,437 \\
100 \%\end{array}$ & $\begin{array}{c}14,686 \\
30 \%\end{array}$ & $\begin{array}{c}1,787 \\
4 \% \\
\end{array}$ & $\begin{array}{c}10,640 \\
22 \%\end{array}$ & $\begin{array}{c}1,791 \\
4 \% \\
\end{array}$ & $\begin{array}{c}3,676 \\
7 \%\end{array}$ & $\begin{array}{l}584 \\
1 \% \\
\end{array}$ & $\begin{array}{c}1,294 \\
3 \% \\
\end{array}$ & $\begin{array}{c}2,135 \\
4 \%\end{array}$ & $\begin{array}{c}11,794 \\
24 \%\end{array}$ & $\begin{array}{c}1,050 \\
2 \%\end{array}$ \\
\hline CAGR & 1.72 & 1.59 & 1.05 & $(1.06)$ & (1.13) & $(0.59)$ & 1.77 & 10.10 & 6.99 & 3.94 & 9.50 \\
\hline \multicolumn{12}{|l|}{ Hg-Cell } \\
\hline 1992 & $\begin{array}{c}12,625 \\
100 \%\end{array}$ & $\begin{array}{c}2,016 \\
16 \%\end{array}$ & $\begin{array}{l}460 \\
4 \%\end{array}$ & $\begin{array}{c}6,984 \\
55 \%\end{array}$ & $\begin{array}{l}1,437 \\
11 \%\end{array}$ & $\begin{array}{l}248 \\
2 \%\end{array}$ & $\begin{array}{l}295 \\
2 \%\end{array}$ & $\begin{array}{l}263 \\
2 \%\end{array}$ & $\begin{array}{l}898 \\
7 \%\end{array}$ & $\begin{array}{l}0 \\
-\end{array}$ & $\begin{array}{c}5 \\
\text { nil }\end{array}$ \\
\hline 1997 & $\begin{array}{c}11,640 \\
100 \%\end{array}$ & $\begin{array}{c}1,809 \\
16 \%\end{array}$ & $\begin{array}{l}424 \\
4 \% \\
\end{array}$ & $\begin{array}{c}6,445 \\
55 \%\end{array}$ & $\begin{array}{l}1,174 \\
10 \%\end{array}$ & $\begin{array}{l}248 \\
2 \%\end{array}$ & $\begin{array}{l}222 \\
2 \%\end{array}$ & $\begin{array}{l}276 \\
2 \%\end{array}$ & $\begin{array}{l}916 \\
8 \%\end{array}$ & $\begin{array}{l}50 \\
\text { nil }\end{array}$ & $\begin{array}{c}5 \\
\text { nil }\end{array}$ \\
\hline CAGR* & $(1.61$ & (2.14) & $(1.62)$ & (1.59) & (3.94) & 0 & $(5.53)$ & 0.97 & 0.40 & nil & 0 \\
\hline \multicolumn{12}{|l|}{$\% \mathrm{Hg}$-Cell } \\
\hline 1992 & 28 & 15 & 27 & 62 & 76 & 7 & 55 & 33 & 59 & 0 & 1 \\
\hline 1997 & 24 & 15 & 24 & 61 & 66 & 7 & 38 & 21 & 43 & nil & nil \\
\hline
\end{tabular}

Lindley (1997) reported major improvements in reducing mercury emissions from mercury cell processes. However, the main emission route is still to air. From 1977 to 1995, the European chloralkali industry reported a drop in mercury emissions from $220 \mathrm{t}$ to $18 \mathrm{t}$, a 92 percent decrease.

\section{Legislative Approaches}

\section{Netherlands}

Maxson and Vonkeman (1996) stated that the Dutch, to encourage recycling, have banned the disposal of mercury-containing wastes, and closed the borders to their export since January 1996. Mercury will only be allowed in products whose life cycles can be controlled.

The Dutch government has implemented strict measures to reduce mercury emissions from industry. The Dutch consider that the health risk to the general population of mercury in the air, food, 
and water is now negligible. The aquatic environment is not well enough understood to fully appreciate the risks, although it is generally agreed that some risk to predators exists (both birds and mammals) that feed on fish and (or) other aquatic organisms. Mercury is still a problem in Dutch soils, and especially in dredged harbor sediments.

Despite the low estimated human risk from mercury, the Dutch government has called for reductions in mercury emissions to soil, water, and air of 80,70 , and 50 percent, respectively, by 2000 relative to 1985 emissions. Actual reductions in emissions of 40, 70, and 65 percent are expected. The ability to meet the target for water emissions is somewhat uncertain, while the target for emissions to soil will clearly be missed, implying that accumulation of mercury in the soil continues. More stringent targets will be set for 2010 , and additional regulatory measures are under consideration.

\section{Sweden and Denmark}

Both Sweden and Denmark have already taken steps to ban the use of mercury in nonessential applications, as reviewed by Maxson and Vonkeman (1996). Furthermore, both countries have committed themselves to closing their borders to the transfer of mercury-bearing wastes. They have therefore had to address questions similar to those being addressed by the Netherlands. The key difference is that both Denmark and Sweden have far less mercury circulating in the environment than the Netherlands, and they do not have such significant secondary sources of mercury. Therefore, neither country expects to have to deal with mercury surpluses as large as those the Netherlands will have to deal with.

Officially, Sweden considers mercury, as an environmental pollutant, to be a global problem requiring an international approach. The main strategy for risk reduction in Sweden is to phase out all uses of mercury. Formal government legislation with regard to products was enacted early in 1991. The importation, manufacture, and sale in Sweden of the following products were prohibited: 
- as of 1 January 1992, mercury in glass thermometers;

- as of 1 January 1993, other mercury-containing thermometers, measuring instruments, and electrical devices including level switches, thermostats, relays and circuit breakers;

- as of 1 January 1995 , mercury-containing pressure switches and electrical contacts for the continuous transfer of current.

The most recent Environmental Government Bill (1993/94:163), which also has the support of Parliament, proposes that all remaining products and uses of mercury, with a few exceptions, should be phased out by the year 2000 or sooner. One notable exception is the continued use of mercury in the chlor-alkali industry, which is permitted until 2010.

Early in the evolution of Danish mercury controls, the Danes had thought that controlling industrial emissions of mercury would be sufficient to reduce human exposure to acceptable levels. It has gradually become clear that this is not sufficient. Products containing mercury are still being produced, and give rise to diffuse mercury pollution during use, and to mercury-containing waste after disposal.

In general, the official Danish position has now developed to the point that exposure of humans to mercury should be kept to an absolute minimum. This can be achieved only by minimizing the use of mercury for all purposes. The long-term goal of the Danish EPA is to bring all uses of mercury to an end.

Through subsidies promoted by the Danish Government for recycling and cleaner technologies, financial support is available for research, development, and dissemination of information promoting substitution and recycling of heavy metals. Projects have been completed concerning the substitution of mercury in products, as well as improved collection aimed at recycling of specific industrial products containing mercury. 
One of the key objectives of The Cleaner Technology Action Plan 1993-97 is to support the development of environmentally safer products. Concerted efforts are being made by industry, research institutions, and others to develop and test, in particular, dental filling materials that do not contain mercury. An evaluation has been carried out for the possibilities of beginning or improving existing arrangements for the collection, recycling, and (or) proper disposal of used products containing mercury, especially electronic equipment and construction/demolition wastes. As part of an ongoing project concerning the recycling of fluorescent light tubes, the possibility of recapturing mercury vapor has been investigated, in order to avoid mercury emissions and potential occupational health problems.

\section{Japan}

Because of several well-publicized industry-related disasters involving pollution by heavy metals, dating as far back as the 1950 's, the Japanese public and industry are particularly sensitized to such issues (Maxson and Vonkeman, 1996). It is generally not considered necessary in Japan to pass legislation aimed at the potential hazards of products. Whenever sufficient consensus develops that might otherwise lead to legislated restrictions, industry "voluntarily" regulates itself to respond to the problem. Target restrictions are set by a consensus between government and industry, and industry is then free to take the measures it considers most appropriate to meet those restrictions. In the case of limit values for pollutants, it is common practice for the Japan Environment Agency (JEA) and industry to agree on a provisional value for the first 5 years, which is then reviewed at the end of that period.

\section{Norway}

Maxson and Vonkeman (1996) commented that the official position of Norway is that mercury is one of the heavy metals whose effects on the environment and on human health are most severe. Risk 
reduction measures should therefore be based on a concern for both health and for the environment. Despite decreases in Norwegian discharges, concentrations continue to increase in the soil and aquatic systems, leading to restrictions on the consumption of certain fish and shellfish.

\section{Brazil}

The gold mining situation in Brazil (representative of similar activity in some other developing countries) is important for several reasons (Maxson and Vonkeman, 1996). First, Brazil is one of the largest present markets for mercury, used extensively in the unsophisticated gold mining operations characteristic of the interior regions of the country. Second, together with similar operations in other developing countries, gold mining is the largest single source of mercury pollution to the environment (especially surface waters) in the world. In the last 20 years, an estimated 1,200 $\mathrm{t}$ of mercury has been emitted to the Brazilian environment due to artisanal gold mining activities! Third, the health effects due to this pollution are already visible among workers and residents in these areas. Fourth, these mining operations, and the use of mercury, have proven nearly impossible for national or regional authorities to control.

\section{Russia, Ukraine, Kyrgyzstan}

Following the disintegration of the FSU, substantial stocks of mercury came onto the international market, according to Maxson and Vonkeman (1996). In desperate need of foreign currency, certain republics offered this mercury at prices as low as 25 percent of the average world price in 1990, according to The Economist in a 1991 report. The European Commission took measures to prevent FSU mercury from being "dumped" on the European market, but the general effect was nevertheless a depression of world prices, which continues to this day.

FSU mines present a curious phenomenon. They are government controlled, but they are likely to be under the influence of one or two key individuals. They are not likely to be subsidized, but 
they are capable of producing mercury at very low cost. Finally, they are likely to sell mercury when certain organizations or individuals need quick cash, rather than when market prices might suggest they should sell. In effect, like State-owned mercury mines in other countries, FSU sales may be little influenced by market conditions. However, FSU sales may have significant influence on world market prices.

\section{CONCLUSIONS}

Environmental concerns, prompted by incidents such as the mercury-caused deaths and injuries at Minamata, Japan, have produced many rules, regulations, and mandates that, over the years, have greatly reduced worldwide mercury production, use, and emissions to the environment.

In the United States, there was no mercury mine production in 1996, whereas $448 \mathrm{t}$ was produced in 1990 . Mercury mine closures, in the early 1990s, were responsible for a significant reduction of mercury to the environment from the milling and roasting of mercury ores. In 1996, secondary production was more than four times the level of secondary production in 1990 . The change from primary mine production to secondary production over the 6-year period is important because it not only eliminated a major source of mercury to the environment, namely $72 \mathrm{t}$ from milling and roasting, but it also reflected an increased awareness for recycling. Much of the recycling occurs in States with mercury recycling mandates, and some of it is subsidized. Recycling of domestic mercury scrap in 1990 occurred at the rate of 130 t per year. In 1996, the rate was $446 \mathrm{t}$, a 243 percent increase.

Domestic mercury use decreased 48 percent from 1990 to 1996. In 1996, mercury flowing into all specified industrial uses was less than 1990 levels: dental use was down 30 percent, laboratory use down 44 percent, measurement and control devices down 62 percent, wiring devices and switches down 30 percent, lighting down 66 percent, chlor-alkali down 45 percent, and mercury use in batteries 
and paints down 100 percent. In 1990, the paint industry added mercury to water-based paints, mainly as a fungicide. In 1996 this use has disappeared. Mercury-containing paints were banned from the market by legislation in 1992. In 1990, mercury-containing dry cell batteries used $105 \mathrm{t}$ of mercury; in 1996 , virtually no mercury went to dry cell batteries.

In 1990, the U.S. government stockpiles released $245 \mathrm{t}$ of mercury to the market. In 1996, there were no sales. Sales were suspended in 1994 pending the release of the Mercury Study Report to Congress (1997b), and have not resumed as of this writing (1999). Mercury imports rose sharply from $15 \mathrm{t}$ in 1990 to $340 \mathrm{t}$ in 1996 . On the other hand, mercury exports decreased dramatically from $311 \mathrm{t}$ in 1990 to $45 \mathrm{t}$ in 1996 . This is a total trade turnaround of $591 \mathrm{t}$, indicating a growing dependence on foreign supply for the remaining mercury needs of the country.

Mercury emissions to the environment in 1996 decreased by $97 \mathrm{t}$ over 1990 levels. Mercury losses from incineration processes decreased by 47 percent between 1990 and 1996. This reduction was a function of less mercury-containing products entering waste streams as well as stack emission controls on incinerators. Mercury disposed in landfills, excluding soil amendments, in 1996 was 61 percent less than in 1990.

With regard to the international production and flow of mercury: all producing mercury mines are foreign; 86 percent of the mercury cell sector of the worldwide chlor-alkali industry is outside of the United States; there is a large trade (2,037 $t$ in 1990 and 1,395 $t$ in 1996) in mercury; and environmental regulations are not internationally uniform.

The Western European region was the world's largest mercury supplier in 1996. Spain, the largest producer within this area, provided 92 percent of this region's total output. The FSU, principally the nations of Kyrgyzstan, Tajikistan, Russia, and Ukraine, was the world's second largest source of mined mercury (785 $\mathrm{t}$ in 1996). PRC has widely scattered, but extensive mercury reserves 
and produced $508 \mathrm{t}$ of mercury in 1996. The nation of Algeria produced $347 \mathrm{t}$ mercury from its mines in 1996, which accounted for all of Africa's production. Global production of mercury in 1996 decreased by $2,019 \mathrm{t}$ over 1990 levels.

Approximately 40 percent of the mercury produced in 1996 was used in the world's chloralkali industry. Western Europe was, by far, the world's largest reservoir of mercury-cell chlor-alkali capacity, and used $631 \mathrm{t}$ mercury in 1996. North America, Eastern Europe, and India/Pakistan were also significant users of mercury $(154,184$, and $133 \mathrm{t}$ respectively) for chlorine production. North America, Western Europe, and northeast Asia were the principal economies using mercury for the production of mercury-containing goods. Major net mercury exporters, in 1996, included Western Europe, the FSU, and Africa. Major net mercury importers, in 1996, included Asia, Eastern Europe, and South America.

PRC is the largest consumer of mercury-containing coal and the largest importer of mercury in the world. In the future, those interested in mercury in the environment will want to know what the flows and their associated emissions are in PRC. Although estimated mercury use by artisanal gold miners in Brazil decreased 50 percent from 1990 to 1996, the impact of the continued use of mercury by artisanal gold miners in countries throughout the world is an important international environmental concern. Additionally, the consequences of mercury mining and production in Tajikistan, Kyrgyzstan, and the Ukraine are of interest because of the uncertainty of environmental control within the states of the FSU. 


\section{SELECTED REFERENCES}

Akelsson, Frank, Mercury balance for the Gothenberg municipality, accessed June 8, 1998 at URL http://vest.gu. se/ bosse/Mercury/Nature/Swedishflow/

Baratov, Oleg, and Skochilov, Yuri, 1996, Geo-ecology and sustainable development of Tajikistan: Ecostan News, accessed July 9, 1998, at URL http://www. friends-partners. org/newfriends/edusci/science/ecostan/ecostan4.6.html.

Center for Mineral Technology (CETEM), 1995, Gold mining (Garimpo) and mercury emissions into the atmosphere: Socio-economic evaluation, in Activities report 1995, p. 11 -12.

Center for Renewable Energy and Sustainable Technology (CREST), Facts about mercury-containing thermostats, accessed May 13, 1998, at URL

http://solstice.crest.org/environment/gotwh/general/hvac-controls/html/mercury.html

Chemical Marketing Association, Inc. (CMAI), Chlorine, world capacity tables: Chemical Marketing Association, Inc., 11601 Katy Frwy, Number 22, Houston, Tex., 48 p.

Chu, Paul, and Porcella, D.B., 1995, Mercury stack emissions from U.S. electric utility power plants, in Porcella, D.B., Huckabee, J.W., and Wheatley, B., eds., Mercury as a global pollutant: Water, Air, and Soil Pollution, v. 80, p. 134-144.

Cimi - Indianist Missionary Council, 1998, Kayapo children and mercury pollution, research by Antonio Barbosa, chemist, university of Brasilia, accessed July 28,1998, at URL http://bioc09.uthscsa.edu/natnet/archive/nl/9410/0267.html

Danish Environmental Protection Agency, 1994, Heavy metals: Redegorelse fra Miljostyrelsen, No. 3 , p. $27-31$.

Drozdiak, William, 1996, The Rhine River is no longer the "sewer of Europe," accessed August 18, 1998, at URL 
http://www.seattletimes.com/extra/browse/html/rhin_032896.html

Farid, L.H., Machaado, J.E.B., and Silva, O.A., 1991, Controle da Emmissao e Recuperacao de Mercurio em Rejritos de Garimpo, in Veiga, M.M., and Fernandes, F.R.C., eds., Pocone-Um Campo de Estudos do Impacto Ambiental do Garimpo: Rio de Janeiro, Brazil, CETEM/CNPq, p. 27-44.

Gobi International, 1998, The gobi report on mercury, CD ROM: version 2.2.

Harris, R.B., Ask the dentist: The Beacon, Virginia Beach, Va., accessed August 20, 1998 at URL http://www.drharris.com/askden.htm.

Heavy Metal Bulletin, 1996, Volume 3, Issue 3, Current amalgam status and restrictions world-wide, accessed May 29, 1998 at URL http://vest.gu.se/-bosse/Mercury/Misc/HMB/amalgamrestrictions.html.

Hedegard, Leif, Amalgam-related illness FAQ, Mercury sources, accessed May 21, 1998, at URL http://hera.algonet.se/ - leif/AmFAQk07.html.

Jasinski, S.M., 1994, The materials flow of mercury in the United States: U.S. Bureau of Mines Information Circular 9412, $28 \mathrm{p}$.

Kenney, C.W., Queneau, P.B., and Hansen, Barry, 1995, State of the art in mercury recycling and Remediation of mercury-containing waste, in International Symposium on the Treatment and Minimization of Heavy Metal-Containing Waste, February 12-16, 1995, Las Vegas, Nev.: Metallurgical Society of the American Institute of Mining and Metallurgical Engineers, $27 \mathrm{p}$. Lindley, A.A., 1997, An economic and environmental analysis of the chlor-alkali productive process - Mercury cells and alternative technologies: Prepared for the European Commission, Directorate-General III, Industry, June 1997, 61 p. 
Lindqvist, Oliver, ed., 1991, Mercury as an environmental pollutant: Water, Air, and Soil Pollution, v. 56,847 p.

Masters, H.B., 1997, Mercury, metals and minerals annual review - 1997: Mining Journal Ltd., p. 80 .

Maxson, P.A., and Vonkeman, G.H., 1996, Mercury stock management in the Netherlands, Background document prepared for the workshop, Mercury: ban it or bridle it?, 21 November 1996: The Hague, Netherlands, Institute for European Policy, Brussels, Belgium, December, 1996, 48 p.

Mercury flow in Sweden, 1997, Swedish mercury consumption and deposits in 1996, accessed May 28, 1998, at URL http://vest.gu.se/ bosse/Mercury/Nature/Swedishflow/flowOne.html.

Mining Journal, 1997, World energy trends, East Europe/CIS slump: Mining Journal, v. 328, no. 8411 , January 10, p. 24.

Mishra, C.P., Wilburn, D.R., Hartos, D.G., Sheng-Fogg, C.D., and Bowyer, R.C., 1985, Mercury availability-Market economy countries: U.S. Bureau of Mines Information Circular 9038, $18 \mathrm{p}$.

Morgan, C.J., 1995, Porgera pollution: Department of Anthropology \& Archaeology, James Cook University, Australia, accessed August 18, 1998, at URL http:/listserv.acsu.buffalo.edu/cgi-bin/wa?A2 =ind9512\&L=anthro-1\&F=\&S=\&P=6490.

National Electrical Manufacturers Association, 1996, The declining presence of mercury in batteries and municipal solid waste: National Electrical Manufacturers Association, Rosslyn, Va., 22 p. 
North Carolina Office of Waste Reduction and Recycling (NCOWRR), 1995, Guidance for used fluorescent lamp management, accessed June 16, 1998, at URL http://www.fac.unc.edu/WasteReduction/fluoresc.htm.

Porcella, Don, Huckabee, John, and Wheatley, Brian, eds., 1995, Mercury as a global pollutant: Water, Air, and Soil Pollution, v. 80, 1336 p.

Rachel's Hazardous Waste News, 1990, Reporting research by Environmental Research Foundation, Annapolis, MD: Rachel's Hazardous Waste News, no. 198, p. 1.

Roskill Information Services Ltd., 1990, The economics of mercury 1990, Seventh Edition: Roskill Information Services Ltd., section 2.10, p. 18.

Takeuchi, Tadao, 1960, Biological reactions and pathological changes in human beings and animals caused by organic mercury contamination, in Hartung, R., and Dinman, B.D., eds., Environmental mercury contamination: Proceedings of the International Conference of Mercury, University of Michigan, 1973, 349 p.

The Chlorine Institute, Inc., 1998, North American chlor-alkali industry plants and production data report - 1997: The Chlorine Institute, Inc., Pamphlet 10, April 1998, 18 p.

----1998, Report to EPA, May 8, 1998: The Chlorine Institute Inc., 2001

L Street N.W., Washington, D.C., 20036-4919, 3 p.

Toxic Release Inventory, 1997, Right-to-Know Network, access varied at URL http://www.rtk.net/trisearch.html.

Trade and Environment Database Case 132, Brazil gold mining and the environment, post 1994, accessed August 18, 1998, at URL http://www.american.edu/projects/mandala/TED/BRAGOLD.HTM. 
Trade and Environment Database Case 245, The environmental database, mercury in Russia, January 1997, accessed July 9, 1998, at URL http://www american edu/projects/mandala/TED/MERCURY.HTM.

U.S. Bureau of Mines, 1970 - 1995, Mineral commodity summaries, Mercury, pages vary.

----1970 - 1994, Minerals Yearbook, Mercury, pages vary.

U.S. Department of Defense, 1998, Strategic and critical materials report to the Congress, October 1997 - September 1998, 48 p.

U.S. Department of Energy, 1998, International energy outlook 1998: EIA-0484 (98), p. 114.

U.S. EPA, 1992, Chlor-alkali, Inorganic Chemical Industry, chapter

8 in Compilation of air pollution emission factors, Fifth Edition, Volume I: U.S.

Environmental Protection Agency, p. 8.11-1 - 8.11-6.

----1997a, Locating and estimating air emissions from

sources of mercury and mercury compounds: U.S. Environmental Protection Agency, Office of Air Quality Planning and Standards, December 1997, EPA-454/R-97-012, pagination varies.

---1997b, Mercury study report to Congress, EPA-452/R-97-003, Eight volume set accessed June 24,1998 at URL http://www.epa.gov/oar/mercury.html.

U.S. Geological Survey, 1997 - 1998, Mineral commodity summaries, Mercury, pages vary.

---1995 - 1997, Minerals Yearbook, Mercury, pages vary.

--Mercury in the geochemical cycle and food chain of the Everglades, accessed May 15,1998, at URL http://snowball.er.usgs.gov/publications/fs/166-96/foodchain.html. 
U.S. Geological Survey and U.S. Bureau of Mines, 1996, Mineral commodity summaries, Mercury, pages vary.

Vanderbilt University Case Study, EcoDS case study: Mercury reduction in fluorescent light bulbs, accessed July 1, 1998, at URL http://shogun.vuse.vanderbilt.edu/gge/CaseStudy/flbgoal.htm.

Veloso de Araujo, R.V., 1995, Gold mining (Garimpo) and mercury emissions into the atmosphere: Socio-Economic Evaluation, Project Report, Center for Mineral Technologies (CETEM), Activities, p. 11 - 12.

Watras, C.J., and Huckabee, J.W., eds., 1994,Mercury pollution, integration and synthesis: Proceedings of International Conference on Mercury as a Global Pollutant, Monterey, California, June 1992, 727 p. 


\section{APPENDIX}

\section{Introduction}

This Appendix sets forth the methodology for the calculations of mercury flow and stocks represented in figures 2 - 13. Figures $2,3,4$, and 11 present a historical perspective on domestic mercury sources and use over the period 1970 to 1997 . In the shorter span between 1990 and 1996, mercury production and use changed dramatically. Many changes were mandated by legislation passed because of concerns about mercury and its impact on the environment. Figures 5-10, 12, and 13 compare domestic mercury flow for 1990 and 1996. Much of the methodology used for the study of mercury flows in 1990 has been retained, but several important changes have been made in the development of the 1996 values. This Appendix explains them in detail. Several elements constrained the development of these data: they had to be consistent among themselves; estimates, where possible, had to agree with authoritative sources; and some rationale was required for estimates where data were not available. In the data tables, column and row data may not add to totals due to independent rounding. The authors welcome suggestions for estimate improvement that are based on better data or more pertinent experience.

\section{Perspective Figures}

Figure 2, Components of U.S. mercury apparent supply (1970 - 1998), was developed from time series data provided by the commodity specialists of the USGS. Domestic apparent supply for each year in the range is shown by a bar having four segments, including net imports, mine production (including by-product), secondary production from scrap, and U.S. Government stockpile releases. (See footnote 2, p. 10.)

Figure 3, U.S. industrial reported consumption of mercury (1970 - 1997), shows how mercury consumption was distributed by sector for the period. Most of the data used to generate figure 3 were 
available. However, values for the laboratory sector had to be estimated for 2 years $(1995,1996)$, where an extrapolation yielded a rate of decline of $2 t$ per year that was extended from the previous 5 years of data.

Pharmaceutical and agricultural usage was reported for the first few years of the period, but not at the end of the series; thus, the values, where reported, were added into the "Other" category, and no delineation for those categories was made.

The breakout of lighting, wiring devices and switches, and batteries did not appear in the series until 1978. Previous to that time, only the total was reported. To show these three categories from 1970 to 1978 , the average of the values for lighting and wiring devices and switches for the years 1978,1979 , and 1980 was used for each year from 1970 through 1977, and the values for batteries for those years were taken to be the difference between the sum of the estimates for lighting and wiring devices and switches and the total reported value for the three.

Figure 4, U.S. apparent supply and reported consumption (1970 - 98), shows how consumer and producer mercury stock changes have been distributed over time. Numbers for most of the supply items were available, but net imports of mercury had to be estimated for the period 1978 to 1988 , during which U.S. exports of mercury were not published. To make this estimate, we assumed a straight-line appreciation of exports from the value of $33 t$ in 1977 to $221 \mathrm{t}$ in 1989, and subtracted the extrapolated values from imports, which were known for this period.

One artifact of the linear growth assumption, especially if the growth was really a step function with a long period of low export levels, is the failure of apparent supply to close with reported consumption, as indicated in figure 4 . The reported consumption line lies above the apparent supply line for most of the period in question. This could lead to a misinterpretation of the period as one of generally decreasing producer/consumer stocks. 
Figure 11, U.S. reported consumption, production, price, and legislation (1970 - 1997), juxtaposes discrete legislation passage dates with the time series data for primary mercury production, reported consumption of mercury, and world mercury price normalized to 1997 dollars.

\section{Comparative Figures}

\section{Figure 5 Versus Figure 6}

In the left third of figure 6 are estimated mercury emissions to the environment from natural sources, fuel combustion, and kiln/smelter activities. To improve the 1996 estimate, the more rigorous estimates made by the EPA in its Mercury Study Report to Congress (1997b) were used. The EPA's estimates were for 1995, and these data have been incorporated into figure 5 as the element titled "Emissions from." Furthermore, the item in figure 6, "Mercury released from natural emissions," was not duplicated in figure 5 because the update (fig. 5) is targeted towards the anthropogenic mercury flow system. "Emissions from" represents actual mercury releases to the environment and excludes a large body of mercury that is retained in landfills from previous mercury disposal activities. The EPA estimated a loss rate from landfills based on effluent gas data, and that small contribution is recorded in figure 5.

The middle third of figure 6 and the middle third of figure 5 are both representations of supply, but different in many important ways. The figure 6 categories "Mercury mine production" and its feeders "Milling and roasting" and "Mercury contained in ore" were dropped from figure 5 because domestic primary mercury mining has been completely replaced by secondary production from scrap. The concept of estimating mercury contributed/released to the environment from production activities was retained, but the EPA's estimates are reported. The net result of both changes is a rather large decrease ( 78 to $0.4 \mathrm{t}$ ) in mercury contribution to the environment from domestic mercury production activities. 
The figure 6 item "Mercury recovered from old scrap" and the figure 5 item "Secondary production" are identical. Note the four-fold increase in supply from this item. State mandates for mercury recycling are largely responsible for this major supply change. The figure 6 item "Recovered at gold mining operations" corresponds to the update's "By-product from gold mining." The original estimate was based on actual survey data. For this update, an estimate of $65 \mathrm{t}$ was reported based on the following observations. In 1991 and 1992, although no primary domestic mercury mine production took place, Mineral Commodity Summaries (MCS) data were reported for both mercury and gold production as shown in table 3 .

Table 3. Mercury and gold production, $1991-1992$, in metric tons.

\begin{tabular}{|l|c|c|}
\hline \multicolumn{1}{|c|}{ Item } & 1991 & 1992 \\
\hline Mercury & 58 & 60 \\
\hline Gold & 290 & 320 \\
\hline Ratio - Mercury:Gold & 0.20 & 0.19 \\
\hline
\end{tabular}

In 1996, gold production was reported by MCS at $326 \mathrm{t}$. Multiplying by the ratio (0.2), the estimate for mercury is 65 t. Kenney and others (1995), using 1994 data, reported that about 30 gold and silver mining/recovery operations collectively recovered about $73 \mathrm{t}$ of by-product mercury using retorts. Whether any of this mercury actually was available to the market rather than being added to producer stocks was not determined.

The terms "Industry stocks (1/1/90)" and "Industry stocks (12/31/90)", which appear in the middle and right third of figure 6 , have been combined into one item, "Net change consumer stocks" (fig. 5). The word "consumer" is used because the MCS footnotes this item as "Consumer stocks only." The convention of subtracting start-of-year from end-of-year stocks is used. This item could have been presented in the "Sources" column in figure 5, where the increasing stocks would have been 
represented by negative flows, but we preferred to keep all flows positive. Therefore, an increase in stocks will be a positive flow in the "Destinations" column.

In the middle sector of figure 6, an item labeled "Unaccounted mercury" is reported as withheld (W). In figure 5, a new item, "Net change producer stocks," was created to distinguish it from consumer stocks, which are directly reported. The methodology for calculating "Net change producer stocks" is as follows: first, the "Destinations" column quantities of "Metal exports" (45 t), "Net changes consumer stocks" (125 t), and "Industrial usage" (372 t), all of which are reported, are totaled (542 t); next, the "Sources" column quantities of "Secondary production" (446 t), "By-product from gold mining" (65 t), "Metal imports" (340 t), "Net change in government stocks" ( 0 t), and "Net change in mercury cells" $(0 t)$ are totaled $(851 \mathrm{t})$; finally, the reported "Destinations" total of $542 \mathrm{t}$ is subtracted from the "Sources" total of $851 \mathrm{t}$ and the difference of $309 \mathrm{t}$ is ascribed to "Net change producer stocks." This amount of mercury is an increase in producer stocks for 1996. Secondary production has completely replaced primary production, and it is uncertain whether either secondary producers, or by-product mercury producers, actually sell all of their production. Therefore, it seemed reasonable to create the producer stock category.

But why would producers increase stocks by an amount equivalent to nearly the total of industrial usage? Table 4 shows the only mercury imported at full market price to be $33 \mathrm{t}$ from Kyrgyzstan. The remaining imports of $307 \mathrm{t}$, an amount approximately the same as the $309 \mathrm{t}$ attribute to producer stocks, came into the United States at less than market price. One conclusion is that the producers were willing, in 1996, to buy mercury at below market prices and hold it for future sales. 
Table 4. U.S. mercury imports, 1996.

\begin{tabular}{|cccc|}
\hline Origin & $\mathbf{t}$ & Value $(1000 \$)$ & $\$ / \mathbf{t}$ \\
\hline Canada & 137 & 791 & 5,770 \\
Kyrgyzstan & 33 & 266 & 8,060 \\
Russia & 79 & 302 & 3,820 \\
Spain & 68 & 327 & 4,810 \\
Other & 23 & 92 & 4,000 \\
\hline Total & 340 & 1,778 & \\
\hline
\end{tabular}

"Released from National Defense \& DOE stockpiles" from figure 6, and "Net change in government stocks" from figure 5 are essentially the same in concept, but the new title seemed more descriptive of the scenario where the government could actually buy mercury (unlikely, but possible), as well as sell it.

A stock in the "Sources" column labeled "Net change in mercury cells" was added to figure 5. The mercury cell process used in production of chlorine in chlor-alkali plants retains over 3,000 $\mathrm{t}$ of mercury. These types of plants, while viable, have been slowly closing. Japan has recycled virtually all of the mercury in its now-closed mercury cells, and for a period of time was a large mercury exporter. Although there was no reported change in the amount of mercury in domestic mercury cells in 1996, the potential for change in the future can be accommodated with this new category.

In figure 6, all the outputs go to a box titled "Total U.S. Supply." This box has been deleted from figure 5, but the total 1996 flow amount $(851 \mathrm{t})$ is shown prior to being split. This amount (851 t) represents mercury metal that will be used for products ("Industrial usage"), inventories changes ("Net change poducer stocks" and "Net change consumer stocks") and exports ("Metal exports").

Finally, figure 5 shows an arrow representing mercury flow from "Industrial usages" going to "Total addition to the environment." This estimate (13.9 t) was taken directly from the EPA Mercury Study Report to Congress (U.S. EPA, 1997b). 


\section{Figure 7 versus Figure 8}

Generally, figure 7 corresponds to figure 8 in concept. Note that mercury embedded in exports and imports of products containing mercury was not included in any of the sectors' analysis.

With the exceptions of the wiring devices and switches sector, which is known to be considerable and growing, and the electric light sector, where imports and exports are approximately equal, the remaining sectors' imports and exports are negligible.

\section{Dental Sector}

It was determined that 90 percent of current year mercury used for dental applications was used in teeth, 8 percent was lost in the dental office in the first year, and 2 percent was lost within 10 years (Jasinski, 1994). Furthermore, Harris (1998) has reported the average life of a mercury amalgam filling to be 5-8 years. Seven years was assumed for the calculation. The updated estimates for mercury flow through the dental sector are illustrated in table 5.

NOTE TO READER: To distinguish among the various values expressed in tables 5 through 12 and 14 and their associated text, the authors provided the following formats. For persons with color printers, blue equals mercury inflows to sectors, red equals mercury in inventories (use), and magenta equals mercury outflows from sectors. For persons with non-color printers, bold text equals blue, italicized text equals red, and underlined text equals magenta.

Table 5. Mercury usage in the dental sector (1986 - 1996) in metric tons.

\begin{tabular}{|c|c|c|c|c|c|c|c|c|c|c|c|c|c|}
\hline & Item & Action & 96 & 95 & 94 & 93 & 92 & 91 & 90 & 89 & 88 & 87 & 86 \\
\hline $\mathrm{A}$ & Sector usage & & 31 & 32 & 24 & 35 & 42 & 41 & 44 & 39 & 53 & 56 & 52 \\
\hline $\mathrm{B}$ & Amt. to fillings & $A^{*} .90$ & & 29 & 22 & 32 & 38 & 37 & 40 & 35 & 48 & & \\
\hline C & $\begin{array}{l}96 \text { flow } \\
\text { from teeth }\end{array}$ & $8^{\text {th }}$ year & & & & & & & & & 48 & & \\
\hline $\bar{D}$ & $\begin{array}{l}\text { Dent. office } \\
\text { loss, } 1^{\text {st }} \mathrm{yr} \text {. }\end{array}$ & $A^{*} .08$ & & 2.60 & & & & & & & & & \\
\hline $\mathrm{E}$ & $\begin{array}{l}\text { Amt. dent. off. } \\
\text { loss }>10 \text { yrs. }\end{array}$ & $A^{*} .02$ & & 0.64 & 0.48 & 0.70 & 0.84 & 0.82 & 0.88 & 0.78 & 1.10 & 1.10 & 1.00 \\
\hline $\bar{F}$ & $\begin{array}{l}10 \% \text { of } 2 \% \\
\text { to ' } 96 \text { outflow }\end{array}$ & $E^{*} .10$ & & 0,06 & 0.05 & 0.07 & 0.08 & 0.08 & 0.09 & 0.08 & 0.11 & 0.11 & 0.10 \\
\hline G & $\begin{array}{l}\text { \% Dent. Off. loss } \\
\text { retained in '96 }\end{array}$ & $\begin{array}{l}\text { Multi- } \\
\text { plier }\end{array}$ & & 0.9 & 0.8 & 0.7 & 0.6 & 0.5 & 0.4 & 0.3 & 0.2 & 0.1 & 0.0 \\
\hline $\mathrm{H}$ & $\begin{array}{l}\text { Amt. to dental. } \\
\text { sect. inventory }\end{array}$ & $\mathrm{G} * \mathrm{E}$ & & 0.58 & 0.38 & 0.49 & 0.50 & 0.41 & 0.35 & 0.23 & 0.22 & 0.11 & 0.00 \\
\hline
\end{tabular}


The amount of mercury added to product stocks in 1996 was reported as $31 \mathrm{t}$ (fig. 7). The mercury retained in products included 7 years' worth of mercury in teeth $(233 t)$ plus the mercury retained in the dental offices, which is eventually lost within 10 years. It is assumed that about $1 / 10$ of the 10-year mercury total is lost every year. The mercury in Row $\mathrm{H}$ represents the 10-year office contribution ( $3 t$ ) that is retained in this sector in 1996. This brings the total 1996 stock to $236 t$. The mercury leaving the sector includes all of the mercury from teeth in the eighth year ${ }^{12}(48 t)$, the mercury lost from dental offices within the first year $(2.6 \mathrm{t})$, and the fraction of mercury that dissipates in 1 year from the mercury that is retained in dental offices for 10 years, the sum of Row $F(0.8 t)$ for a total of $51 \mathrm{t}$. The $51 \mathrm{t}$ of mercury that exited the dental sector in 1996 split into $46 \mathrm{t}$ recycled, and by difference, $5 \mathrm{t}$ into dissipative (incineration and landfill) loss. This split is based on the assumption that 90 percent of mercury generated by the dental sector is recycled, mostly as spent fillings that are being replaced yearly, or new mercury collected within dental offices from amalgam scrap.

\section{Laboratory Sector}

Because mercury usage for 1996 was withheld, the estimate for 1996 was based on the consistent annual decrease of $2 \mathrm{t}$ between 1990 and 1994. Therefore, this sector usage was estimated at $20 \mathrm{t}$ in 1996.

The EPA reported that mercury is used in laboratories in instruments, and as reagents and catalysts. Without specific data on the distribution of mercury to these three subsectors, we assumed that $1 / 3$ of the annual input goes to each subsector. The life within each subsector was based on the EPA's estimate of a 5-year life for instruments, reagent 1 year, and catalyst 2 years. Applying these assumptions allowed us to generate table 6 , which provides the mercury flows through this sector.

\footnotetext{
${ }^{12}$ As a rule, whenever there were no data about the fraction of mercury that each year contributes to sector outflow, that is, no recognizable distribution, we applied the convention that the next year's sector usage (the first year beyond the average life of the product) was a fair representation of the outflow from the sector.
} 
Table 6. Mercury usage in the laboratory sector $(1990-1996)$ in metric tons.

\begin{tabular}{|ccccc|}
\hline Year & Usage & $\begin{array}{c}\text { Instruments } \\
(33.3 \%)\end{array}$ & $\begin{array}{c}\text { Reagents } \\
(33.3 \%)\end{array}$ & $\begin{array}{c}\text { Catalysts } \\
(33.3 \%)\end{array}$ \\
\hline 1996 & $\mathrm{~W}, \mathbf{2 0} 0^{\circ}$ & & & \\
1995 & $\mathrm{~W}, 22^{\circ}$ & 7.3 & 7.3 & 8.3 \\
1994 & 24 & 8.0 & & 8.0 \\
1993 & 26 & 8.7 & & \\
1992 & 28 & 9.3 & & \\
1991 & 30 & 10.0 & & \\
1990 & 32 & 10.7 & & \\
\hline W = estimated, & & & & \\
W= withheld & & & & \\
\hline
\end{tabular}

The amount of mercury going into laboratory product applications in 1996 is estimated to be 20 t. The mercury retained in the laboratory sector includes 5 years' worth of mercury in instruments $(43 t)$ plus 1 year's worth of mercury in reagents $(7 t)$, plus 2 years' worth of mercury in catalysts (15 t), a total of 65 t. Mercury exiting the laboratory sector in 1996 includes the sixth year of mercury in instruments $(\underline{11} \mathrm{t})$ the second year of mercury in reagents $(\underline{8 t})$, plus the third year of mercury in catalysts $(2 \mathrm{t})$, a total of $\underline{28 \mathrm{t}}$. The $28 \mathrm{t}$ of mercury that leaves the laboratory sector in 1996 splits into a $25 \mathrm{t}$ flow into recycling, and, by difference, a $3 \mathrm{t}$ flow into dissipative (incineration and landfill) loss (fig. 7). This split is based on the assumption that 90 percent of mercury generated by the laboratory sector is recycled, mostly as spent instruments and catalysts.

\section{Measurement/Control Devices Sector}

Table 7 contains mercury usage provided by the USGS for measurement and control devices for the last 7 years. In 1996, 41 t of mercury went into product applications. In addition to these base data, the EPA reports that the major portion of mercury production in this sector is thermometers, which have an estimated average life of 5 years.

Table 7. Mercury usage in the measurement and control devices sector $(1990$ - 1996) in metric tons.

\begin{tabular}{|lccccccc|}
\hline & 1990 & 1991 & 1992 & 1993 & 1994 & 1995 & 1996 \\
\hline Hg use & 108 & 90 & 80 & 65 & 53 & 43 & 41 \\
\hline
\end{tabular}


The mercury retained in products includes 5 years' worth of mercury used for this sector ( 331 t). Mercury exiting this sector in 1996 was $108 \mathrm{t}$, which was 1990 's mercury use. The $108 \mathrm{t}$ of mercury that left the measurement/control devices sector in 1996 was split in half, $54 \mathrm{t}$ each flowed into recycling and into dissipative (incineration and landfill) loss. The 50 percent assumption, based on recycling, is arbitrary, yet seems reasonable given the fact that these devices are widely spread throughout society.

\section{Wiring Devices/Switches Sector}

Neglecting mercury imports for wiring devices and switches, which could be substantial in this sector, the amount of mercury going into product applications in 1996 was reported in the USGS Minerals Yearbook as 49 t. The EPA's Mercury Study Report to Congress (U.S. EPA, 1997b) noted that electrical switches containing mercury were not manufactured prior to the 1960 's. This study also reported that 10 percent of electrical switches were discarded after 10 years, 40 percent after 30 years, and 50 percent after 50 years, and that thermostats had approximately a 20 -year life. The results of incorporating this information into the estimates are shown in table 8. 
Table 8. Mercury usage in the wiring devices and switches sector (1963 - 1996) in metric tons.

\begin{tabular}{|c|c|c|c|c|}
\hline Year & $\begin{array}{l}\text { Usage } \\
\text { (A) }\end{array}$ & $\begin{array}{l}\text { Accumulation of } \\
\text { mercury outflow } \\
\text { (B) }\end{array}$ & $\begin{array}{l}\text { Contribution to } \\
1996 \text { outflow } \\
\text { (C) }\end{array}$ & $\begin{array}{l}\text { Contribution to } \\
\text { product inventory } \\
\text { (D) }\end{array}$ \\
\hline 1996 & 49 & & & \\
\hline 1995 & 84 & $1 \%, \quad 1$ & $1 \%, 0.8$ & $99 \%, 83$ \\
\hline 1994 & 79 & $2 \%, \quad 2$ & $1 \%, 0.8$ & $98 \%, 77$ \\
\hline 1993 & 83 & $3 \%, \quad 3$ & $1 \%, 0.8$ & $97 \%, 80$ \\
\hline 1992 & 82 & $4 \%, \quad 3$ & $1 \%, 0.9$ & $96 \%, 79$ \\
\hline 1991 & 71 & $5 \%, 4$ & $1 \%, 0.7$ & $95 \%, 67$ \\
\hline 1990 & 70 & $6 \%, 4$ & $1 \%, 0.7$ & $94 \%, 66$ \\
\hline 1989 & 141 & $7 \%, 10$ & $1 \%, 1.4$ & $93 \%, 130$ \\
\hline 1988 & 176 & $8 \%, 14$ & $1 \%, 1.8$ & $92 \%, 160$ \\
\hline 1987 & 131 & $9 \%, 12$ & $1 \%, 1.3$ & $91 \%, 119$ \\
\hline 1986 & 103 & $10 \%, 10$ & $1 \%, 1.0$ & $90 \%, 93$ \\
\hline 1985 & 95 & $11 \%, 11$ & $1 \%, 1.0$ & $89 \%, 84$ \\
\hline 1984 & 94 & $12 \%, 11$ & $1 \%, 0.9$ & $88 \%, 83$ \\
\hline 1983 & 80 & $13 \%, 10$ & $1 \%, 0.7$ & $87 \%, 70$ \\
\hline 1982 & 69 & $14 \%, 10$ & $1 \%, 0.7$ & $86 \%, 59$ \\
\hline 1981 & 91 & $15 \%, 14$ & $1 \%, 0.9$ & $85 \%, 77$ \\
\hline 1980 & 106 & $16 \%, 17$ & $1 \%, 1.0$ & $84 \%, 89$ \\
\hline 1979 & 111 & $17 \%, 19$ & $1 \%, 1.1$ & $83 \%, 92$ \\
\hline 1978 & 110 & $18 \%, 20$ & $1 \%, 1.1$ & $82 \%, 90$ \\
\hline 1977 & $103 *$ & $19 \%, 20$ & $1 \%, 1.0$ & $81 \%, 83$ \\
\hline 1976 & 103 & $20 \%, 21$ & $1 \%, 1.0$ & $80 \%, 82$ \\
\hline 1975 & 103 & $21 \%, 22$ & $1 \%, 1.0$ & $79 \%, 81$ \\
\hline 1974 & 103 & $22 \%, 23$ & $1 \%, 1.0$ & $78 \%, 80$ \\
\hline 1973 & 103 & $23 \%, 24$ & $1 \%, 1.0$ & $77 \%, 79$ \\
\hline 1972 & 103 & $24 \%, 25$ & $1 \%, 1.0$ & $76 \%, 78$ \\
\hline 1971 & 103 & $25 \%, 26$ & $\underline{1 \%, 1.0}$ & $75 \%, 77$ \\
\hline 1970 & 103 & $26 \%, 27$ & $1 \%, 1.0$ & $74 \%, 76$ \\
\hline 1969 & 103 & $27 \%, 28$ & $1 \%, 1.0$ & $73 \%, 75$ \\
\hline 1968 & 103 & $28 \%, 29$ & $1 \%, 1.0$ & $72 \%, 74$ \\
\hline 1967 & 103 & $29 \%, 30$ & $1 \%, 1.0$ & $71 \%, 73$ \\
\hline 1965 & 103 & $30 \%, 31$ & $1 \%, 1.0$ & $70 \%, 72$ \\
\hline 1964 & 103 & $31 \%, 32$ & $1 \%, 1.0$ & $69 \%, 71$ \\
\hline 1963 & 103 & $32 \%, 33$ & $1 \%, 10$ & 689,70 \\
\hline
\end{tabular}

${ }^{*}$ Based on the EPA statement that production was constant at 1 million units, mercury input for the unreported early years was estimated to be the average of production from 1978 through 1986, excluding recession years 1982 and 1983.

The mercury retained in product is the sum of the numbers in column $\mathrm{D}(2,670 \mathrm{t})$, which was determined by subtracting the 1 percent per year wasting rate from the reported yearly usage. Mercury exiting this sector in 1996 is the sum in column C ( $32 t)$ that splits into two equally divided streams of $16 \mathrm{t}$ each. Again, this split is based on the assumption that 50 percent of mercury generated by this sector will be recycled. 


\section{Electric Light Sector}

The electric light sector includes both fluorescent lamps and high-intensity discharge lamps

(HID). The EPA reported ${ }^{13}$ the following: the average mercury content of each fluorescent lamp unit has decreased from 46 to 23 milligrams over the period 1990 - 1995; the 1992 split between

fluorescent and HID lamps is 96:4 (confirmed by Kenney and others (1995), for 1996 production);

HID lamps average about 62 milligrams mercury per unit; and the average life of both fluorescent and

HID lamps is 4 years. Table 9 shows the decrease in mercury content, per fluorescent lamp, by year.

Table 9. Mercury content in a fluorescent lamp (1990 - 1996) in milligrams.

\begin{tabular}{|cccccccc|}
\hline Year & 1990 & 1991 & 1992 & 1993 & 1994 & 1995 & 1996 \\
\hline $\mathrm{Hg}$ & 46 & 38 & 34 & 30 & 27 & 23 & 19 \\
\hline
\end{tabular}

The figures for 1990 and 1995 in the table are reported values, and the remaining figures are extrapolated estimates. The assumption is a straight-line decrease in mercury content.

Table 10 illustrates the methodology for calculating the mercury flow through the electric light sector.

Lamp production and sales were extracted from the DOC's data, and the mercury usage from the USGS Minerals Yearbook was based on lamp wholesaler survey estimates. Disregarding mercury imports and exports ${ }^{14}$ (equal in 1996) of fluorescent and HID lamps, the amount of mercury going into product applications in 1996 was estimated to be $11 \mathrm{t}$. The mercury retained in products included 4 years' accumulation of mercury usage for this sector $(64 t)$ and the mercury exiting this sector in 1996 equals the total mercury usage calculated from $1991(23 \mathrm{t})$.

\footnotetext{
${ }^{13}$ Incorporating National Electrical Manufacturer's Association (NEMA) data.

${ }^{14}$ If this sector's flow analysis is updated in the future, the analyst will want to obtain more data on imports. PRC, a major mercury producer, has also become one of the world's largest producers and exporters of electric lamps.
} 
Table 10. Mercury usage in the electric light sector (1991 - 1996).

\begin{tabular}{|ccccccccc|}
\hline Year & $\begin{array}{c}\text { Lamp } \\
\text { production } \\
\text { (millions) }\end{array}$ & $\begin{array}{c}\text { Fluorescent } \\
\text { fraction } \\
(96 \%)\end{array}$ & $\begin{array}{c}\text { Hg per unit } \\
\text { (milligrams) }\end{array}$ & $\begin{array}{c}\text { Hg usage } \\
(\mathrm{t})\end{array}$ & $\begin{array}{c}\text { HID } \\
\text { fraction } \\
(4 \%)\end{array}$ & $\begin{array}{c}\text { Hg per unit } \\
\text { (milligrams) }\end{array}$ & $\begin{array}{c}\text { Hg usage } \\
\text { (t) }\end{array}$ & $\begin{array}{c}\text { Total Hg } \\
\text { usage } \\
(t)\end{array}$ \\
\hline 1996 & 550 & 528 & 19 & 10 & 22 & 62 & 1.4 & 11 \\
1995 & 550 & 528 & 23 & 12 & 22 & 62 & 1.4 & 13 \\
1994 & 550 & 528 & 27 & 14 & 22 & 62 & 1.4 & 1.5 \\
1993 & 550 & 528 & 30 & 16 & 22 & 62 & 1.4 & 17 \\
1992 & 550 & 528 & 34 & 18 & 22 & 62 & 1.4 & 19 \\
1991 & 550 & 528 & 42 & 22 & 22 & 62 & 1.4 & 23 \\
\hline
\end{tabular}

The stream split was based on the lamp-recycling rate reported by Kenney and others (1995). They determined that in 1995, the United States had capacity ( 24 hour operation, 300 days per year) to recycle 60 percent of lamp production. However, only about 1/5 of capacity was being utilized. This calculates out to approximately $3 \mathrm{t}$. Therefore, the electric light sector in 1996 split into a $3 \mathrm{t}$ flow into recycling, and a $20 \mathrm{t}$ flow into dissipative (incineration and landfill) loss.

\section{Batteries Sector}

Although mercury batteries were no longer being produced in 1996, some of the mercurycontaining batteries from prior years' production were still in the system. Despite the fact that inservice batteries retain their utility for as long as 2 years, Kenney and others (1995) reported that the mean retention time for batteries in households was 4 years. The 4-year life estimate was used to calculate the mercury in product inventory based on usage listed in table 11.

Table 11. Mercury usage in the battery sector (1991 - 1996), in metric tons.

\begin{tabular}{|lcccccc|}
\hline & 1991 & 1992 & 1993 & 1994 & 1995 & 1996 \\
\hline Hg use & 18 & 13 & 10 & 6 & 3 & 0 \\
\hline
\end{tabular}

The mercury retained in product includes 4 years' worth of mercury used for this sector (32t). Mercury exiting this sector in 1996 includes the fifth year of sector mercury use (18 t). The split into recycling ( $2 t)$ and dissipative loss ( $16 t)$ is based on the assumption that 10 percent of mercury generated by this sector is recycled. The 10 percent assumption is arbitrarily based on the fact that 
batteries are widely spread throughout society, and the level of adherence to recycling mercury mandates is high, to keep these materials out of municipal solid waste.

\section{Chlor-Alkali Sector}

Mercury usage in the chlor-alkali industry has decreased due to the decreasing proportion of mercury cells making up chlorine production capacity and tighter mercury recycling in the mercury cell subsector. The mercury flowing through the chlor-alkali sector is shown in table 12.

Table 12. Mercury usage in the chlor-alkali sector (1991 - 1996), in metric tons.

\begin{tabular}{|lcccccc|}
\hline & 1991 & 1992 & 1993 & 1994 & 1995 & 1996 \\
\hline Hg use & 184 & 209 & 180 & 135 & 154 & 136 \\
\hline
\end{tabular}

The amount of mercury going into this process was $136 \mathrm{t}$ in 1996 . The mercury retained in the process, actually within the working mercury cells, is estimated to be $2,770 \mathrm{t}$. Additionally, the industry's on-site recycling activity contains an inventory of $134 \mathrm{t}$, and a make-up inventory of purchased mercury of $150 \mathrm{t}$. The sum of these three inventories represents the industry's total working mercury inventory of 3,050 t. The mercury leaving this sector is estimated from EPA TRI data and is discussed in the next paragraph.

A figure of $136 \mathrm{t}$ of mercury leaving the sector in 1996 is based on the fact that $136 \mathrm{t}$ of mercury was purchased in 1996: The system being essentially in equilibrium requires purchases to make-up for system losses. The Toxic Release Inventory data informs that $19 \mathrm{t}$ flow into landfills, $7 \mathrm{t}$ flow into off-site recycling, and $8 \mathrm{t}$ is lost to fugitive and stack emissions. One can estimate, based on plant data, that about $1 \mathrm{t}$ leaves the plant associated with impurities in the caustic product. This leaves $101 \mathrm{t}$ of outflows from the chlor-alkali industry as unaccounted. For the development of figure 7 , the only concern was with the mercury leaving the system for off-site recycling and for land filling. This total is $26 \mathrm{t}$. 


\section{Other Sector}

Table 13 demonstrates how end-use mercury reporting has changed over the years, as percent of total usage in the various sectors.

Table 13. - Reported mercury end-use categories $(1970,1980,1996)$, in percent. $[\ll$, much less than; $w$, withheld; NR, not reported]

\begin{tabular}{|l|c|c|c|}
\hline \multicolumn{1}{|c|}{ Category } & 1970 & 1980 & 1996 \\
\hline Agriculture & 4 & $\mathrm{~W}$ & $\mathrm{NR}$ \\
Amalgamation & $<<1$ & $\mathrm{NR}$ & $\mathrm{NR}$ \\
Catalysts & 4 & $\mathrm{NR}$ & $\mathrm{NR}$ \\
Dental preparations & $<<1$ & $\mathrm{NR}$ & 8 \\
Electrical apparatus & 23 & $\mathrm{NR}$ & $\mathrm{NR}$ \\
Lights & part of electrical apparatus & $\mathrm{W}$ & 8 \\
Wiring Devices/Switches & part of electrical apparatus & 5 & 13 \\
Batteries & part of electrical apparatus & 38 & 0 \\
Other electrical & part of electrical apparatus & $\mathrm{W}$ & $\mathrm{NR}$ \\
Chlor-Alkali & 30 & 24 & 37 \\
Laboratory & 1 & $<<1$ & W \\
Measurement/Control Devices & 4 & 3 & 11 \\
Paint & 21 & 22 & $\mathrm{NR}$ \\
Pulp/Paper & $<<1$ & $\mathrm{NR}$ & $\mathrm{NR}$ \\
Pharmaceuticals & $<<1$ & $\mathrm{NR}$ & $\mathrm{NR}$ \\
Other & 11 & 7 & 23 \\
\hline
\end{tabular}

The following assumptions about the flows through this category were made. A product life of 3 years and a 10 percent recycling rate for this category were chosen based on assumptions made for prior sectors. The mercury flowing through the "Other" sector is shown in table 14.

Table 14. Mercury usage in the "Other" sector (1992 - 1996), in metric tons.

\begin{tabular}{|lccccc|}
\hline & 1992 & 1993 & 1994 & 1995 & 1996 \\
\hline Hg use & 112 & 121 & 135 & 93 & 84 \\
\hline
\end{tabular}

The amount of mercury going into product inventories in 1996 is estimated to be $84 \mathrm{t}$. The mercury retained in product includes 3 years' worth of mercury used for this sector (349t). Mercury exiting this sector in 1996 includes the fourth year of sector mercury use $(112 \mathrm{t})$. The $112 \mathrm{t}$ of 
mercury that leaves the sector in 1996 splits into a $11 \mathrm{t}$ flow into recycling ( 10 percent), and, by difference, a $101 \mathrm{t}$ flow into dissipative (incineration and landfill) loss.

\section{Unaccounted Sector}

The purpose for this category is to make the "Outflows" sum to the totals in the "Disposition" column of figure 7. It is an artifact of the methodology used. With regard to "Secondary production," 64 percent is "Unaccounted." With regard to "Landfill" and "Incineration loss," 33 percent is "Unaccounted." Further research is suggested to reduce the relative size of the contribution from the "Unaccounted" section.

\section{Obsolete Product Disposition Estimates}

The "Disposition" column in figure 7 has three categories: "Secondary production" to represent recycled material; "Incineration loss" to represent the fraction of mercury that is released to the environment from municipal waste combustors (MWC), medical waste incinerators (MWI), hazardous waste combustors (HWC), cement kilns, and sewage waste combustors; and ' Land or landfill," which includes mercury contained in items that are applied to land as soil amendment or that are directly landfilled, and collected mercury from incineration activities.

The subcategory "Secondary production" is the connection between figure 5 and figure 7 . The $446 \mathrm{t}$ of mercury from figure 5 establishes the limit in figure 7 for the sum of recycled materials from the industry sectors.

The EPA, in its Mercury Study Report to Congress, estimated mercury incineration losses as follows: $26.9 \mathrm{t}$ from MWC, 14.6 $\mathrm{t}$ from MWI, $6.4 \mathrm{t}$ from HWC, $4.4 \mathrm{t}$ from cement kilns, and $1 \mathrm{t}$ from sewage sludge incineration, a total of $53.3 \mathrm{t}$. 
The EPA reported mercury collection efficiencies for various control devices as follows: Flue gas desulfurization 30.85 percent; spray dryers 25.59 percent; fabric filters 28.47 percent; electrostatic precipitators 23.98 percent. It was assumed that 27 percent applied overall.

The total mercury going into all types of incinerators would be:

$$
\text { Mercury }_{\text {input }}=53.3 /(1-0.27)=73 \mathrm{t}
$$

Approximately 12 percent of generated municipal solid waste (MSW) goes into MWC; the remainder is directly landfilled. Correspondingly, about 95 percent of medical waste goes into MWI, 95 percent of hazardous waste goes into HWC, or cement kilns, and 26 percent of sewage sludge is incinerated, 36 percent is used as soil amendment, and 38 percent is directly landfilled.

The total mercury going into municipal waste combustors in 1996 would be:

$$
\text { Mercury }_{\text {input to }} \mathrm{MWC}=26.9 /(1-0.27)=37 \mathrm{t}
$$

The total mercury in MSW would be:

$$
\text { Mercury }_{\text {MSW }}=37 / 0.12=308 \mathrm{t}
$$

The mercury from MSW going to the landfill would be:

$$
\text { Mercury }_{\text {Landfill }}=308-37=271 \mathrm{t}
$$

The mercury from the MWC going to the landfill would be:

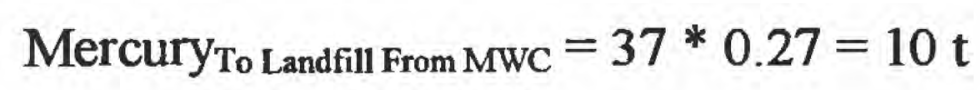

The total mercury from MSW, the amount going directly, and the amount from MWC, going to the landfill would be $(271+10)=281 \mathrm{t}$. Similarly, the total mercury from MW going to the landfill is $7 \mathrm{t}$, the total mercury from HW going to the landfill is $4 \mathrm{t}$, and the total mercury from sewage sludge incineration is $1 \mathrm{t}$. The total mercury input to landfills from these sources would be $295 \mathrm{t}$ (fig. 7). 


\section{Figure 9 Versus Figure 10}

In 1996, the industry purchased $136 \mathrm{t}$ of mercury to service a make-up mercury inventory, estimated from the average of 3 years $(1995,1996$, and 1997) of annual purchases to be about $150 \mathrm{t}$. In addition to the make-up inventory, the industry retains about $134 \mathrm{t}$ of mercury in its on-site recycling activities and about $2,770 \mathrm{t}$ in the mercury cells themselves. The sum of these three inventories represents the industry's total working mercury inventory of $3,050 \mathrm{t}$, as shown in figure 7 .

The mercury leaving the industry is estimated from EPA Toxic Release Inventory data as follows: $19 \mathrm{t}$ flow into landfills, $7 \mathrm{t}$ flow into off-site recycling, and $8 \mathrm{t}$ lost to fugitive and stack emissions.

Some mercury is known to leave the system attached to the caustic product, which is mainly used at paper mills. This is about $1 / 2 t$ per year (rounded to $1 \mathrm{t}$ in fig. 9). This leaves $101 \mathrm{t}$ of outflow from the chlor-alkali industry as unaccounted; this number is incorporated into the $116 \mathrm{t}$ which outflows from the "Unknown" sector listed under the "Product/process stocks 1/1/96" in figure 7.

The estimate of the amount of mercury contained, and continuously recycled, through mercury cells in chlor-alkali plants was derived as follows: Art Dungen (Chlorine Institute, written commun., December 11, 1998), reported that 14 mercury-cell plants were operating in the United States in 1996. Within these plants, there were a total of 726 working mercury cells. A single mercury cell contains between 7,000 and 10,000 pounds of mercury. Given this information, it was assumed that the distribution of 7 - 10 thousand pound mercury cells was normal, such that the average of 8,500 pounds mercury per cell applied. The estimate for mercury in mercury cells was therefore:

$$
\text { Mercury }_{\text {total in Hg-cells }}=8,500 \mathrm{lb} / \text { cell } * 726 \text { cells } * 0.90718 / 2,000=2,800 \mathrm{t}
$$

F. Anscombe (EPA, oral communi., December 11, 1999) reported that one mercury cell plant of which he had knowledge held 200,000 pounds of mercury in 24 cells. This calculates to 8,330 pounds 
mercury per cell. Using this number to replace the 8,500 in the calculation above yields a total of 2,740 t. Averaging the two estimates gives 2,770 $\mathrm{t}$ of mercury residing in mercury cells (fig. 9).

From figure 9, $150 \mathrm{t}$ of make-up mercury, $134 \mathrm{t}$ of mercury cycling within the recycle loop, and $2,770 \mathrm{t}$ of mercury in cells were added to obtain the $3,050 \mathrm{t}$ estimate of total mercury within the chlor-alkali segment of the industry.

Figure 10 shows flows in 1990 . The chlor-alkali industry purchased $247 \mathrm{t}$ of mercury to service a make-up mercury inventory, estimated from the average of 5 years $(1988,1989,1990,1991$, and 1992) of annual purchases to be about $275 \mathrm{t}$. In addition to the make-up inventory, the industry retained about $153 \mathrm{t}$ of mercury in its on-site recycling activities, and about $3,170 \mathrm{t}$ in the mercury cells themselves. These estimates were made by taking the ratio of chlorine capacity for 1990 and 1996. The sum of these three inventories represents the industry's total working mercury inventory of $3,600 \mathrm{t}$ in 1990 .

The mercury leaving the industry in 1990 is estimated from EPA Toxic Release Inventory data as $60 \mathrm{t}$ flow into landfills, no flow into off-site recycling, and $9 \mathrm{t}$ lost to fugitive and stack emissions.

Some mercury is known to leave the system attached to the caustic product, which is mainly used at paper mills. This is about $1 / 2 \mathrm{t}$ per year (rounded to $1 \mathrm{t}$ in fig. 10). This leaves $177 \mathrm{t}$ of outflow from the chlor-alkali industry as unaccounted in 1990 .

\section{Figure 12 Versus Figure 13}

Table 15 contains the data for the production, use, and flow of mercury on a global basis and underlies the presentation in figures 12 and 13. 
Table 15. Global mercury production, use, and flow 1990 and 1996 in metric tons. [n.a., not available]

\begin{tabular}{|c|c|c|c|c|c|c|c|c|c|c|c|c|}
\hline \multirow[t]{3}{*}{ Region } & \multirow{2}{*}{\multicolumn{2}{|c|}{ Production }} & \multicolumn{8}{|c|}{ Use } & \multirow{2}{*}{\multicolumn{2}{|c|}{ Net flow }} \\
\hline & & & \multicolumn{2}{|c|}{ Chlor-alkali } & \multicolumn{2}{|c|}{ Manufactures } & \multicolumn{2}{|c|}{ Artisanal gold } & \multicolumn{2}{|c|}{ Stock changes } & & \\
\hline & 1990 & 1996 & 1990 & 1996 & 1990 & 1996 & 1990 & 1996 & 1990 & 1996 & 1990 & 1996 \\
\hline $\begin{array}{l}\text { North } \\
\text { America }\end{array}$ & 1,297 & 526 & 319 & 154 & 553 & 238 & n.a & n.a & 255 & 84 & -170 & -50 \\
\hline $\begin{array}{l}\text { South } \\
\text { America }\end{array}$ & 0 & 5 & 72 & 62 & 65 & 20 & 200 & 100 & 34 & 18 & +371 & +195 \\
\hline $\begin{array}{l}\text { West } \\
\text { Europe }\end{array}$ & 882 & 1,141 & 1,067 & 631 & 440 & 177 & n.a. & n.a. & $-1,165$ & -30 & -540 & -363 \\
\hline $\begin{array}{l}\text { East } \\
\text { Europe }\end{array}$ & 163 & 25 & 209 & 184 & 88 & 28 & n.a. & n.a. & 30 & 21 & +164 & +208 \\
\hline FSU & 1,400 & 785 & 34 & 34 & 150 & 60 & n.a. & n.a. & 459 & 9 & -757 & -682 \\
\hline $\begin{array}{l}\text { Middle } \\
\text { East }\end{array}$ & 47 & $\underline{0}$ & 101 & 81 & 35 & 18 & n.a. & n.a. & 7 & 5 & +96 & +104 \\
\hline Africa & 637 & 347 & 43 & 36 & 21 & 9 & unknown & unknown & 3 & 2 & -570 & -300 \\
\hline $\begin{array}{l}\text { India } \\
\text { and } \\
\text { Pakistan }\end{array}$ & 0 & 0 & 138 & 133 & 66 & 30 & n.a. & n.a. & 20 & 16 & +224 & +179 \\
\hline NE.Asia & 930 & 508 & 0 & 5 & 375 & $\$ 45$ & unknown & unknown & 1,688 & 701 & $+1,133$ & +643 \\
\hline SE. Asia & 0 & 0 & 20 & 24 & 25 & 36 & unknown & whknown & 4 & 6 & +49 & +66 \\
\hline $\begin{array}{l}\text { World } \\
\text { Total }\end{array}$ & 5,356 & 3,337 & 2,003 & $1,3+4$ & 1,818 & 1,061 & $200+$ & $100+$ & 1,335 & 832 & 0 & 0 \\
\hline
\end{tabular}

\section{Countries Within Regions}

For table 15, the listed "Regions" include the following countries: North America - Canada, Mexico, and United States; South America - Central and South America; West Europe - Belgium, Denmark, Finland, France, Germany, Greece, Ireland, Italy, Luxembourg, Norway, Portugal, Spain, Sweden, Switzerland, and United Kingdom; East Europe - Albania, Bulgaria, Czech Republic, BosniaHerzegovina, Federal Republic of Yugoslavia, Hungary, Macedonia, Poland, Romania, Slovakia, and Slovenia; FSU - Kyrgyzstan, Tajikistan, Russia, and Ukraine; Middle East - Iran, Iraq, Israel, Jordan, Saudi Arabia, Turkey, and United Arab Emirates; Africa - Algeria, Egypt, Gabon, Libya, Morocco, South Africa, and Tunisia; India - Pakistan: India and Pakistan; Northeast Asia - PRC, Japan, Korea, and Taiwan; Southeast Asia - Australia, Indonesia, Singapore, and Thailand. 


\section{Production}

"Production" was taken from the Gobi Report (Gobi, 1998). Some discrepancies exist between the Gobi production data and the USGS data for the years in question. For example, total global mercury production for 1990 was $4,100 \mathrm{t}$ according to USGS sources, and 5,356 t according to Gobi. Likewise, USGS reported total mercury production in 1996 as 2,795 t, versus 3,337 t by Gobi. As the Gobi Report provided the most complete set of trade flows, and considering that flow patterns were more important than flow precision, the Gobi production data were used for this part of the analysis.

\section{Uses}

This part of the table 15 delineates four mercury uses: chlor-alkali production in mercury cells; manufactured products that contain mercury; artisanal gold mining; and stock changes. These parameters were estimated as shown.

\section{Chlor-alkali Production}

Chemical Marketing Association Inc. (CMAI, 1999) provided a complete global listing of chlor-alkali plant capacity, broken out by production method, which allowed the isolation of each country's mercury-cell chlorine capacity. Country estimates for mercury usage in chlor-alkali production were calculated by multiplying the mercury-cell chlorine capacity by the U.S. ratios as follows: (annual mercury purchases for mercury cells) / (mercury cell capacity).

The above ratio was different for 1990 and 1996, 0.1444 versus $0.0918 \mathrm{t}$ mercury per thousand metric tons mercury cell chlorine capacity, respectively. The decrease in mercury usage rate was attributable to increased efficiencies in the operation of mercury-cell chlor-alkali plants in the United States, and tightened controls on system mercury losses, both of which are indicated by reduced purchases of mercury. 
We assumed that some of the developing countries, had not accomplished the same increased mercury-cell efficiencies and loss controls as had the United States. Therefore, the 1990 ratio (less efficient than 1996 ratio and requiring higher use for same capacity) was utilized to estimate 1996 mercury use for those countries.

\section{Manufactures (Products Containing Mercury)}

Except for the United States, very little international sector (dental, instruments, lighting, and others) information was available. A reasonable estimate was feasible for the chlor-alkali industry from the existing data, but was not possible for other sectors. We decided to estimate the total amount of mercury that would likely be going into manufactured products for each country. The following assumptions were made: each country has a level of economic sophistication proportional to that of the United States; total chlorine production capacity (chlorine production being ubiquitous throughout the world) for each country is a good indicator of economic sophistication; and supporting data must be available for each country. Accordingly, annual ratios for the years 1990 and 1996 were calculated as follows: (U.S. mercury purchases for mercury-containing products) / (Total U.S. chlorine production capacity).

Again, this ratio basis was different for 1990 and 1996, 0.0401 versus $0.0165 \mathrm{t}$ mercury per thousand metric tons total chlorine capacity, respectively. The decrease in mercury usage rate was attributed to legislation that mandated reductions in mercury use in products, technological advances in lighting leading to reduced mercury use in that sector, and tightened controls on system mercury losses through recycling.

Following the same line of reasoning as in the previous chlor-alkali calculations, the assumption was made that developing countries had not passed the same mercury-conscious legislation as had the United States. For such countries, the 1990 ratio was applied to 1996 total 
chlorine production capacities for the purpose of estimating 1996 mercury use for the manufacture of mercury-containing products. Specifically, only Western Europe, Japan, and Australia were considered to be progressing economically, technologically, and legislatively along the same track as the United States.

\section{Anecdotal Information}

The data in the Manufactures column, table 15, was not broken into individual sectors. The following information provides additional insights as to the state of each of these sectors.

\section{Dentistry}

Domestically, the use of mercury in dental applications has remained almost constant since 1980. Recently, concerns about the use of mercury-silver amalgams in women either pregnant or contemplating pregnancy has arisen because of evidence that the fetus preferentially takes mercury from the mother's body. The use of mercury in dental amalgams ( 50 percent) is being seriously debated worldwide. As reported by Heavy Metal Bulletin (1996), the replacement of amalgam (with ceramics) has been suggested in Sweden, Finland, Denmark, and Norway. Canada, Germany, Austria, and Sweden have recommended legally nonbinding restrictions for mercury amalgams. Japanese dentists are directly responsible for the safe disposal of mercury. Amalgam separators are legal requirements in Sweden, Norway, Germany, and Switzerland. In Denmark, mercury-containing product sales have been banned since 1994, with the exception of amalgam. Germany and Austria have laws to outlaw amalgam by the year 2000 .

\section{Batteries}

Mercury-oxide batteries have been banned from commercial use in the United States and Europe. Demand for this product has been eliminated entirely in these areas. Although PRC has legislation on the books that will eliminate mercury-oxide battery production by the year 2002 , the 
question of how many are being produced currently is unanswered. Whatever the number, the use is restricted to developing countries because such products cannot be exported to the United States or Europe. The substitutes for mercury-oxide batteries all contain traces of mercury, and batteryrecycling programs have developed worldwide.

Button batteries, primarily "button type" containing mercury, are still produced by Gold Peak (Hong Kong) and other companies. They are not used in consumer devices in United States. However, the Ever Ready amplifier battery, EP-675, may still be manufactured by the Ever Ready Company for use (overseas) in hearing aids.

\section{Fungicides}

Fungicides containing mercury are no longer produced in developed countries. Mercurycontaining fungicides were previously added to latex paints. Agriculturally, mercury-containing fungicides were used to control brown mold in freshly sawn lumber and to combat Dutch elm disease and snow mold. Some golf courses still use mercury-containing fungicides. As with batteries, these uses have been controlled or prohibited by law in developed countries. Again, no reliable information exists about production and use in developing countries, although there have been reports (Iraq) of local poisonings from grains treated with mercury-containing fungicides.

\section{Fluorescent Lamps}

Fluorescent lamps contain about 200 parts per million mercury. From 1985 to 1995 the mercury content of fluorescent lamps has decreased by 35 percent (NCOWRR, 1995). PRC is a major producer of fluorescent lamps; however, few data are available on Chinese lamp production, use, disposition, and trade. Chinese fluorescent lamps could conceivably be a vehicle for mercury flow into the United States. 


\section{Laboratory Chemicals}

Mercury used in laboratories in many cases finds its way into the municipal water treatment plant, where it goes straight through into receiving waters. With regard to the international use and disposal of laboratory chemicals, no data are available.

\section{Electronic Equipment}

Electronic equipment such as thermostats and electrical switches can contain significant amounts of mercury. With regard to the international use and disposal of electrical equipment, no data are available.

The Danish Environmental Protection Agency (1994) reported that from 1977 to 1990 , mercury use declined from $31 \mathrm{t}$ to about $11.5 \mathrm{t}$ (63 percent), closely tracking the U.S. experience. Although it is not reported in this way in other European countries, one may infer from European Union environmental legislation and the quality of annual mercury flow monitoring reports that Europe is reducing mercury use through product bans. Whether this is occurring in developing countries to the same degree is an open question.

\section{Artisanal Gold}

One of the greatest environmental concerns is associated with artisan gold mining in the Amazon basin. The Center for Mineral Technology (CETEM, 1995), Brazil, estimated that $140 \mathrm{t}$ of mercury were being used every year by artisanal gold miners in the Amazon region. In 1990, 50 percent of reported gold production was from artisanal miners. In 1996, only 20 percent of reported gold production was by artisanal gold miners. In table 15 , the artisanal gold miner's use of $200 \mathrm{t}$ mercury in 1990 and $100 \mathrm{t}$ mercury in 1996 were extrapolated from the CETEM estimate and reported artisanal gold production. 


\section{Stock Changes}

The parameter "Stock changes" is an artifact established to balance production, use, and flow (net imports). Information regarding stock changes on a country-by-country basis was limited. Any information available was used, and flow was estimated or adjusted. In some cases, it was estimated for a subject country as either 5 or 10 percent (based on economic sophistication) of the sum of estimated mercury use for chlor-alkali and manufactures for that particular country.

\section{Net Flows}

"Net flows" was extracted directly from trade flow data contained in the Gobi Report. Net flow data were not available for all countries. For countries where net flow data were unavailable, an estimate was made to balance production and use. The assumption was made that global net flow summed to zero. 